\title{
In Situ Stress Analysis of Wellbore Breakouts from Oklahoma and the Texas Panhandle
}

\section{U.S. GEOLOGICAL SURVEY BULLETIN 1866-F}

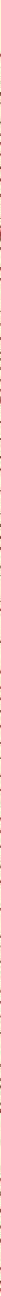




\section{AVAILABILITY OF BOOKS AND MAPS OF THE U.S. GEOLOGICAL SURVEY}

Instructions on ordering publications of the U.S. Geological Survey, along with prices of the last offerings, are given in the current-year issues of the monthly catalog "New Publications of the U.S. Geological Survey." Prices of available U.S. Geological Survey publications released prior to the current year are listed in the most recent annual "Price and Availability List." Publications that are listed in various U.S. Geological Survey catalogs (see back inside cover) but not listed in the most recent annual "Price and Availability List" are no longer available.

Prices of reports released to the open files are given in the listing "U.S. Geological Survey Open-File Reports," updated month1y, which is for sale in microfiche from the U.S. Geological Survey, Books and Open-File Reports Section, Federal Center, Box 25425, Denver, CO 80225. Reports released through the NTIS may be obtained by writing to the National Technical Information Service, U.S. Department of Commerce, Springfield, VA 22161; please include NTIS report number with inquiry.

Order U.S. Geological Survey publications by mail or over the counter from the offices given below.

\section{BY MAIL}

\section{Books}

Professional Papers, Bulletins, Water-Supply Papers, Techniques of Water-Resources Investigations, Circulars, publications of general interest (such as leaflets, pamphlets, booklets), single copies of Earthquakes \& Volcanoes, Preliminary Determination of Epicenters, and some miscellaneous reports, including some of the foregoing series that have gone out of print at the Superintendent of Documents, are obtainable by mail from

\section{U.S. Geological Survey, Books and Open-File Reports Federal Center, Box 25425 Denver, CO 80225}

Subscriptions to periodicals (Earthquakes \& Volcanoes and Preliminary Determination of Epicenters) can be obtained ONLY from the

\section{Superintendent of Documents Government Printing Office Washington, D.C. 20402}

(Check or money order must be payable to Superintendent of Documents.)

\section{Maps}

For maps, address mail orders to

$$
\begin{aligned}
& \text { U.S. Geological Survey, Map Distribution } \\
& \text { Federal Center, Box } 25286 \\
& \text { Denver, CO } 80225
\end{aligned}
$$

Residents of Alaska may order maps from

\author{
Alaska Distribution Section, U.S. Geological Survey, \\ New Federal Building - Box 12 \\ 101 Twelfth Ave., Fairbanks, AK 99701
}

\section{OVER THE COUNTER}

\section{Books}

Books of the U.S. Geological Survey are available over the counter at the following Geological Survey Public Inquiries Offices, all of which are authorized agents of the Superintendent of Documents:

- WASHINGTON, D.C.--Main Interior Bldg., 2600 corridor, 18 th and C Sts., NW.

- DENVER, Colorado--Federal Bldg., Rm. 169, 1961 Stout St.

- LOS ANGELES, California--Federal Eldg., Rm. 7638, 300 N. Los Angeles St.

- MENLO PARK, California--Bldg. 3 (Stop 533), Rm. 3128, 345 Middlefield Rd.

- RESTON, Virginia--503 National Center, Rm. 1C402, 12201 Sunrise Valley Dr.

- SALT LAKE CITY, Utah--Federal Bldg., Rm. 8105, 125 South State St.

- SAN FRANCISCO, California--Customhouse, Rm. 504, 555 Battery St.

- SPOKANE, Washington--U.S. Courthouse, Rm. 678, West 920 Riverside Ave.

- ANCHORAGE, Alaska--Rm. 101, 4230 University Dr.

- ANCHORAGE, Alaska--Federal Bldg, Rm. E-146, 701 C St.

\section{Maps}

Maps may be purchased over the counter at the U.S. Geological Survey offices where books are sold (all addresses in above list) and at the following Geological Survey offices:

- ROLLA, Missouri--1400 Independence Rd.

- DENVER, Colorado--Map Distribution, Bldg. 810, Federal Center

- FAIRBANKS, Alaska--New Federal Bldg., 101 Twelfth Ave. 
Chapter F

\section{In Situ Stress Analysis of Wellbore Breakouts from Oklahoma and the Texas Panhandle}

\section{By RICHARD L. DART}

A multidisciplinary approach to research studies of sedimentary rocks and their constituents and the evolution of sedimentary basins, both ancient and modern 
DEPARTMENT OF THE INTERIOR

MANUEL LUJAN, JR., Secretary

U.S. GEOLOGICAL SURVEY

Dallas L. Peck, Director

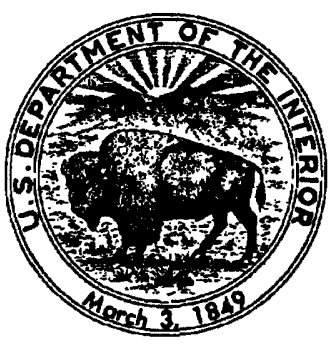

Any use of trade, product, or firm names in this publication is for descriptive

purposes only and does not imply endorsement by the U.S. Government.

UNITED STATES GOVERNMENT PRINTING OFFICE: 1990

For sale by the

Books and Open-File Reports Section

U.S. Geological Survey

Federal Center

Box 25425

Denver, CO 80225

Library of Congress Cataloging-in-Publication Data

Dart, R.L. (Richard L.)

In situ stress analysis of wellbore breakouts from Oklahoma and the Texas Panhandle / by Richard L. Dart.

p. $\quad \mathrm{cm}$. - (Evolution of sedimentary basins-Anadarko Basin ; ch. F)

(U.S. Geological Survey bulletin ; 1866-F)

Includes bibliogiaphical references (p. )

Supt. of Docs. no.: I 19.3:1866-F

1. Rock deformation-Oklahoma. 2. Rock deformation-Texas.

3. Earth-Crust. I. Title . II. Series. III. Series: U.S. Geological Survey bulletin ; 1866-F.

QE75.B9 no. 1866-F

[QE604]

$557.3 \mathrm{~s}-\mathrm{dc} 20$

[557.8'09766] 


\title{
CONTENTS
}

\author{
Abstract F1 \\ Introduction $\quad \mathbf{F 1}$ \\ Geologic setting $\quad$ F2 \\ Wellbore enlargement data F5 \\ Rock types of enlargement formation $\quad F 8$ \\ Fracture enlargements and data scatter F11 \\ Inferred stress directions and relative stress magnitudes $\quad$ F17 \\ Transpressional (oblique compressional) stresses and fault-bounded blocks \\ Conclusions F25 \\ References cited $\mathbf{F 2 5}$
}

\section{FIGURES}

1-4. Maps showing:

1. Generalized structure of Oklahoma and the Texas Panhandle F3

2. Structure of the eastern Anadarko basin F4

3. Structure of the Marietta basin F6

4. Structure of the Bravo dome area F7

5. Cross sectional schematics of wellbores showing original and enlarged borehole shapes $\mathbf{F 8}$

6-8. Three-dimensional histograms and frequency rose diagrams for the:

6. Eastern Anadarko basin F9

7. Marietta basin F10

8. Bravo dome area $\quad$ F12

9. Vertical bar graphs of wellbore enlargement type and rock type of enlargement occurrence $\quad \mathbf{F 1 8}$

10. Histogram of wellbore enlargement data $\quad$ F24

\section{TABLE}

1. Quality criteria for breakout (wellbore enlargment) data F13

2-4. Wellbore enlargement data for the:

2. Eastern Anadarko basin F14

3. Marietta basin F15

4. Bravo dome area F16

5. Stratigraphic units logged F20

6. Wellbore enlargement type, frequency of occurrence, and orientation $\quad$ F22

7. In situ stress data, south-central United States F23

8. Inferred stress directions from wellbore enlargment orientations $\quad \mathbf{F 2 3}$

9. Comparison of wellbore enlargement data from different stress regimes $\mathbf{F 2 3}$ 


\title{
In Situ Stress Analysis of Wellbore Breakouts from Oklahoma and the Texas Panhandle
}

\author{
By Richard L. Dart
}

\section{Abstract}

Orientations of crustal stresses are inferred from stressinduced breakouts (wellbore enlargements) in the eastern part of the Anadarko basin in central Oklahoma, the Marietta basin in south-central Oklahoma, and the Bravo dome area of the central Texas Panhandle. Inferred directions of maximum horizontal principal stress $\left(\mathrm{SH}_{\max }\right)$ are east-northeast for the eastern Anadarko basin and northeast for the Marietta basin and the Bravo dome area.

The relative magnitudes of the three principal stresses $\left(S_{1}, S_{2}, S_{3}\right)$ are known for the Bravo dome area from existing hydraulic-fracturing measurements, and a normal-faulting stress regime $\left(\mathrm{S}_{\mathrm{V}}>\mathrm{SH}_{\max }>\mathrm{SH}_{\min }\right)$ is implied. For the eastern Anadarko basin and the Marietta basin, the magnitudes of the principal stresses are not known. Possible left-lateral oblique slip on the Meers fault during the Quaternary implies that strike-slip $\left(\mathrm{SH}_{\max }>\mathrm{S}_{\mathrm{V}}>\mathrm{SH}_{\min }\right)$ and reverse $\left(\mathrm{SH}_{\max }\right.$ $>\mathrm{SH}_{\mathrm{m} / \mathrm{n}}>\mathrm{S}_{\mathrm{V}}$ ) faulting has occurred in south-central Oklahoma. Thus, the study region may be a transition zone between extensional stress in the Texas Panhandle and compressional stress in Oklahoma.

Breakout data from the eastern Anadarko basin yield a single consistent $\mathrm{SH}_{\max }$ orientation, whereas data from the Marietta basin and the Bravo dome area yield bimodalorthogonal distributions believed to consist of northwestoriented breakouts and northeast-oriented fracture-related wellbore enlargements. This northeast (orthogonal) trend in data from the Marietta basin and the Bravo Dome area is probably related to drilling-induced hydraulic fracturing of the wellbore or to preexisting natural fractures or joint sets intersecting the wellbore. On dipmeter log records, breakouts and fracture-related enlargements have similar elliptical cross sections. Orthogonally oriented breakout and fracturerelated wellbore enlargements are therefore differentiated by comparing their long-axis orientations with directions of known or inferred horizontal stress.

Manuscript approved for publication, January 10, 1990.
The mean orientations of either the breakout or fracturerelated orthogonal trends in the Marietta basin and the Bravo dome area data sets are not as well constrained as the mean orientation of breakout data for the eastern Anadarko basin. Poorly constrained mean orientations give the appearance of data scatter or dispersion among wellbore enlargement orientations within the northwest and northeast bimodalorthogonal trends. Drill holes in the Marietta basin and Bravo dome area are located primarily between northwest-striking subparallel faults. Mean data orientations calculated for either orthogonal trend for individual well data sets appear to rotate counterclockwise across these two fault-bounded study areas. Stress trajectory rotation between suparallel faults within the Marietta basin and the Bravo dome study areas may account for the data scatter.

Although breakouts and fracture-related enlargements formed in all parts of the thick sequences of sedimentary rocks logged, they are primarily in limestone, shale, and dolomitic rock, probably because of the abundance of these rock types.

\section{INTRODUCTION}

Numerous borehole stress studies (Cox, 1970; Brown, 1978; Bell and Gough, 1979, 1982; Gough and Bell, 1981, 1982; Hickman and others, 1985; Plumb and Hickman, 1985; Teufel, 1985; Zoback and others, 1985) and theoretical and laboratory studies simulating borehole stress conditions (Mastin, 1984; Haimson and Herrick, 1985; Zoback and others, 1985) show that wellbore breakouts are stress-induced spall zones that typically elongate vertically within the wellbore and are the result of compressional shear failure of the wellbore associated with unequal horizontal compressive stresses about the wellbore. Wellbore breakouts are elliptical in cross section and are aligned in the direction of minimum horizontal compressive stress $\left(\mathrm{SH}_{\min }\right)$. The idea that breakouts reflect local in situ stress conditions is supported by the agreement between stress directions 
inferred from breakouts and stress orientations obtained using other types of stress data such as earthquake focal mechanisms, hydraulic-fracturing measurements, and geologic indicators of stress (Gough and Bell, 1981, 1982; Hickman and others, 1985; Plumb and Hickman, 1985; Dart and Zoback, 1989).

Breakout-data analysis is an important tool in understanding present-day stress conditions in areas where more detailed stress measurements are not available. An understanding of in situ stress conditions is essential in evaluating seismic hazards, recent crustal deformation, and the potential for slip on existing faults. In the petroleum industry, knowledge of borehole stress conditions can be critical in the engineering and design of drilling operations and hydraulic-fracturing treatments (Dart and Zoback, 1989).

The eastern Anadarko basin, Marieta basin, and Bravo dome area were selected for study on the basis of data availability, proximity to the Anadarko basin, and involvement in the structural and tectonic evolution of Oklahoma and the Texas Panhandle. This paper offers a more detailed analysis of data presented in earlier reports (Dart, 1987; Dart and Zoback, 1987).

Acknowledgments.-I thank the following individuals and companies for the generous assistance in acquiring much of the data needed for this study: David Walker (Baker and Taylor Drilling Co., Amarillo, Tex.); Mark Ramsey and E.G. Kerns (Cities Service Oil and Gas Corp., Oklahoma City, Okla.); Bill Osten (Phillips Petroleum Co., Oklahoma City, Okla.); T.A. Deines, Stephen O'Niell, and P.L. Clymer (Marathon Oil Co., Midland, Tex.); J.A. Norton (Consolidated Oil and Gas, Inc., Denver, Colo.); Greg Riepl (States Petroleum Inc., Irving, Tex.); D.J. Wechsler, Daniel Hanson, and M.D. Wittstrom (Chevron U.S.A. Inc., Oklahoma City, Okla.); Jackie Ritchey and Bill Clement (AnSon Gas Corp., Oklahoma City, Okla.); Ted Price (Samedan Oil Corp., Oklahoma City, Okla.); S.A. Maier (The Anchutz Corp., Oklahoma City, Okla.), Phil Schrenier and A.R. Dowell (Texaco U.S.A., Denver, Colo.); and Tom Verolust (Mustang Production Co., Oklahoma City, Okla.).

Conversations with D.G. Davis of the Colorado School of Mines and W.J. Perry Jr., S.H. Frezon, M.L. Zoback, and H.S. Swolfs of the U.S. Geological Survey were very helpful in clarifying a number of important points. I am indebted to W.J. Perry Jr., H.S. Swolfs, J. Schmoker, M. Cecil, and M.L. Zoback for their critical reviews of the text.

\section{GEOLOGIC SETTING}

Located on the boundary between the Great Plains and Central Lowlands physiographic provinces, the study area (fig. 1) is a region of deep sedimentary basins filled with thick sequences of Paleozoic marine rocks separated by uplifted basement structures of Cambrian and Precambrian igneous and metamorphic rocks (Jordan, 1967; Johnson and others, 1972; Johnson and Denison, 1973; Johnson and others, 1984). The primary west-northwest structural trend of basins and basement highs extends across southern Oklahoma into the Texas Panhandle. This trend developed in the Paleozoic Era during periods of basement faulting, igneous intrusion, basin subsidence, and orogenic deformation (Ham and others, 1964; Hoffman and others, 1974; Wickham, 1978; Perry, 1989). The stratigraphic history of the region is dominated by episodes of carbonate and shale deposition attributed to eustatic fluctuations and intervals of clastic deposition associated with subareal erosion of uplifted areas.

The eastern Anadarko basin underlies most of central Oklahoma (figs. 1 and 2). It is bounded on the south by the Amarillo-Wichita uplift, the Marietta and Ardmore basins, and the Arbuckle uplift and on the east by the Nemaha ridge. The Frontal fault system forms a reverse-faulted zone of detachment that separates the Anadarko basin to the north from the Amarillo-Wichita uplift (Gilbert, 1983; Perry, 1989). The basin is deepest along this boundary; an accumulation of more than $40,000 \mathrm{ft}$ of Paleozoic sediments forms the most complete Paleozoic section in the Midcontinent structural province (Adler and others, 1971). This Cambrian to Permian section is composed of Cambrian to Mississippian carbonate rocks and shale unconformably overlain by Pennsylvanian to Permian clastic sedimentary rocks (Petroleum Information Corporation, 1982). The lower part of this section formed during a period of shallow marine deposition and rapid basin subsidence (Feinstein, 1981); the upper part was deposited in response to erosion of the Amarillo-Wichita and Criner uplifts to the south and east of the basin (Moore, 1979). Faulting along the eastern and southern boundaries of the basin occurred during the formation of the AmarilloWichita uplift and in response to compressional tectonism associated with uplift of the Ouachita Mountains and the Nemaha ridge (fig. 1) (Gilbert and Donovan, 1982; Burchett and others, 1985). Evidence of recent movement on faults within the Frontal fault system in southern Oklahoma is supported by geomorphic and stratigraphic data. Ramelli and others (1987) and Luza and others (1987) have documented Quaternary oblique slip with down-to-the-south movement on the Meers fault and possible recent movement on the Washita Valley fault.

The Marietta basin in Oklahoma (figs. 1 and 3) at the eastern end of the Amarillo-Wichita uplift is within the Southern Oklahoma aulacogen. This northwesttrending synclinal structure is bounded on the northeast by the Criner uplift and on the southwest by the WaurikaMuenster uplift. The early depositional history of this area, which predates the formation of the Marietta 


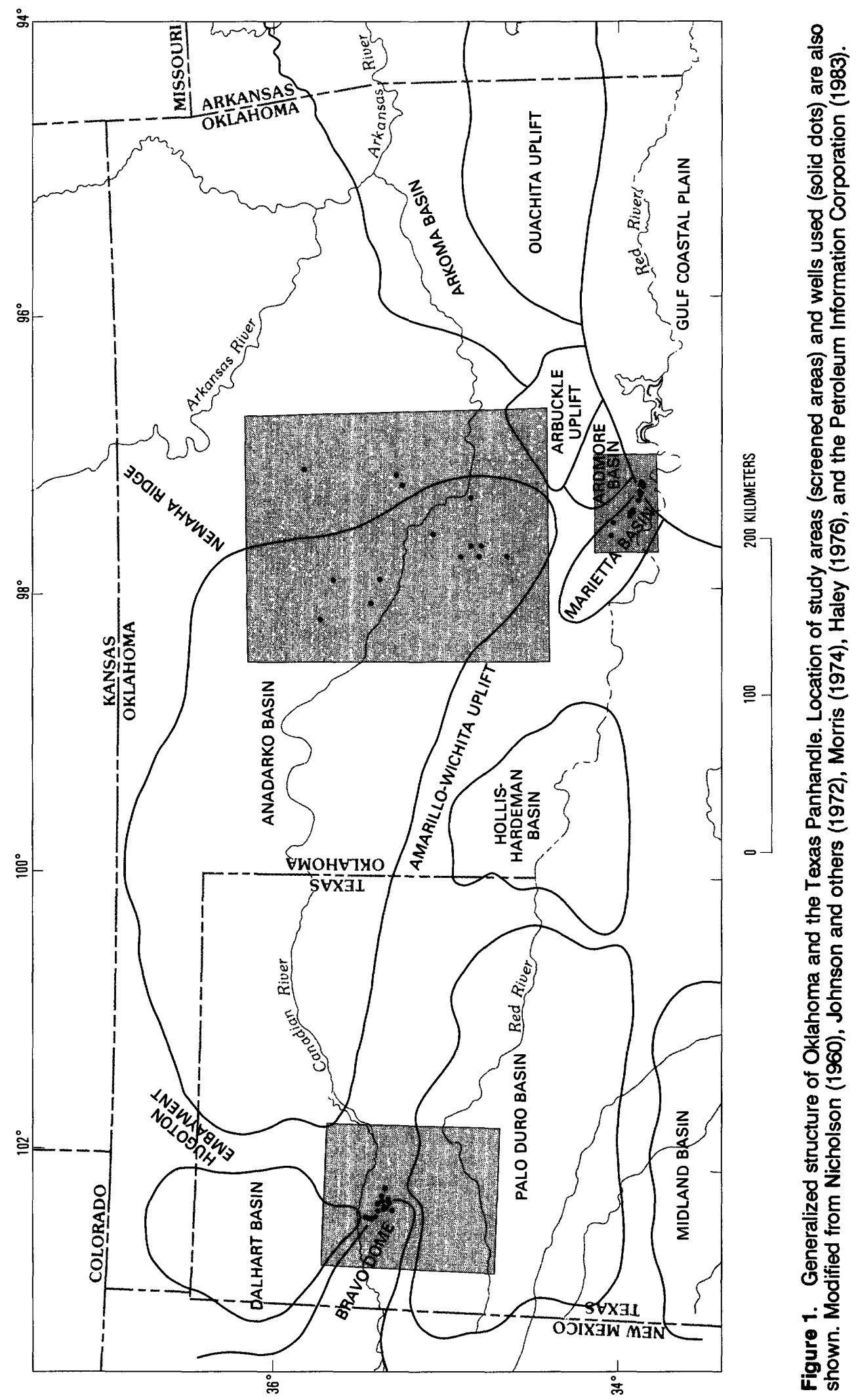



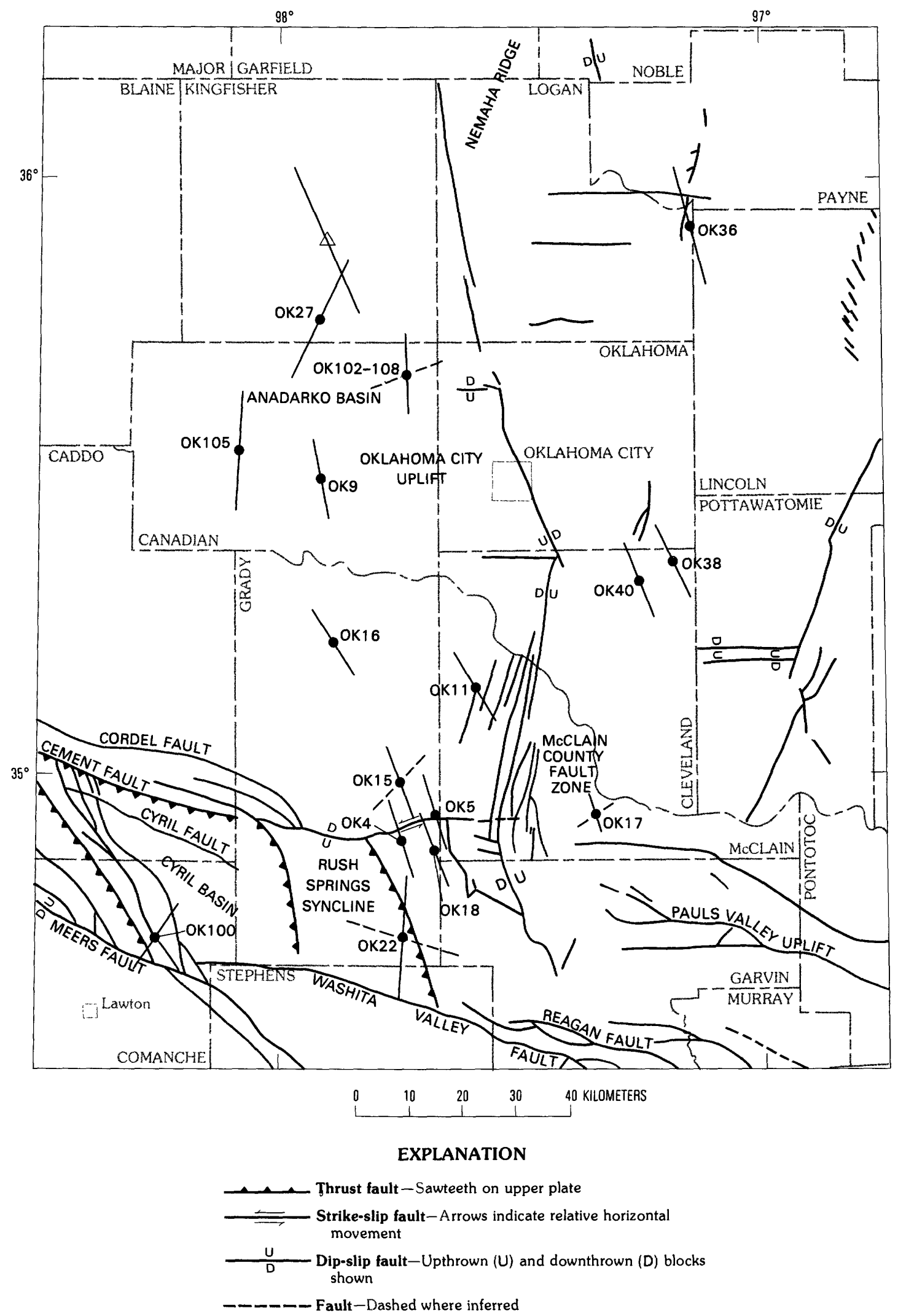
syncline, involves deposition of a thick sequence of Cambrian to Ordovician carbonate rocks overlain by Upper Ordovician through Lower Mississippian limestone, sandstone, and shale (Henry, 1968).

The Wichita orogeny in Late Mississippian to Middle Pennsylvanian (early Atokan) time and the Arbuckle orogeny in early Desmoinesian to early Virgilian time were significant events in the structural and depositional histories of the Marietta basin (Tomlinson and McBee, 1959). Formation of the Criner and Muenster-Waurika uplifts and faulting and folding associated with initial development of the Marietta syncline accompanied the Wichita orogeny (Tomlinson and McBee, 1959). Early syncline development is possibly associated with deformation of the Southern Oklahoma aulacogen (Wickham, 1978). Significant deposition within the syncline did not begin until late Middle Pennsylvanian (Desmoinesian) time (Frederickson and Redman, 1965). The Marietta syncline was little affected by tectonism of the Arbuckle orogeny. During this period of orogenic activity, the Criner uplift acted as a structural barrier to southwest compressional stresses and associated crustal shortening and faulting (Frederickson and Redman, 1965). At the close of the Pennsylvanian Period, however, Virgilian- and Permian-age sediments were eroded from the Arbuckle Mountains and deposited over the area (Frederickson and Redman, 1965). Basin subsidence associated with sediment loading continued into post-Permian time (Frederickson and Redman, 1965).

The Bravo dome (figs. 1 and 4), located within the larger Permian basin, is a Late Mississippian to Early Pennsylvanian tectonic feature between the Dalhart and Palo Duro basins (Budnik and Smith, 1982). Formation of the Bravo dome coincided with development of the Amarillo-Wichita uplift. By mid-Permian time, carbonate and clastic (arkosic) sedimentary rocks deposited in response to Late Mississippian to Early Pennsylvanian tectonism completely covered structural features such as the Bravo dome and filled the smaller basins in the region (McGookey and Goldstein, 1982). Within this part of the Texas Panhandle, a sequence of Permian-age halitebearing formations interbedded with marine mudstone,

Figure 2 (facing page). Structure map of the eastern Anadarko basin. Direction of wellbore enlargement is indicated by dot with solid line; line length is proportional to statistical quality (A-C); for example, OK27 is B quality, and OK16 is C quality. Bimodal-orthogonal data sets and data sets that are not bimodal but do have orthogonal data are indicated by paired solid lines and paired solid and dashed lines, respectively. Line lengths for some bimodal-orthogonal and orthogonal data sets are commonly shorter because of D-quality standard deviations. Open triangle with line indicates hydraulic fracturing data (von Schonfeldt and others, 1973). Structural features from Chenoweth (1972). siltstone, anhydrite, and dolomite units covers the Bravo dome structure (Presley, 1980). This overlaying sedimentary accumulation is cut by a series of northweststriking high-angle faults that define basement structures (fig. 4) (Dutton and others, 1982). The most prominent of these is the Potter County fault, which separates the Bravo dome from the Dalhart basin. Basement faults associated with Paleozoic tectonism of the AmarilloWichita uplift are probably reverse faults (Dutton and others, 1982). Deformation, associated with these faults, of late Tertiary-age Ogallala Formation strata is indicative of Cenozoic fault movement in the Texas Panhandle (Budnik, 1987).

\section{WELLBORE ENLARGEMENT DATA}

Wellbore enlargement (breakout) stress data are the measured long-axis orientations of stress-related elliptical features on standard four-arm, high-resolution dipmeter and fracture-identification well logs. Breakoutstress studies are economical because of the availability of well-log data through institutional, commercial, and industrial sources.

Two types of wellbore enlargements are important to this study: (1) stress-induced breakouts associated with shear failure of the wellbore, and (2) orthogonally oriented, stress-related fracture borehole enlargements likely associated with either drilling-induced hydraulic fracturing of the wellbore or favorably oriented preexisting fractures or closely spaced joint sets intersecting the wellbore (fig. 5) (Dart and Zoback, 1989). Fracturerelated wellbore enlargements should be oriented in the direction of $\mathrm{SH}_{\max }$, perpendicular to the trend of breakouts in the same well, creating an orthogonal-bimodal distribution of enlargement orientations. Fracturerelated enlargements due to preexisting fractures reflect the trend of these fractures. Whether hydrostatically induced or preexisting, fractures intersecting the borehole probably aid in the formation of stress-related, elliptically shaped wellbore enlargements.

Statistically, wellbore enlargement data sets are treated as axially symmetric, circular-normal distributions of two-dimensional vectors (Batschelet, 1965; Dart, 1987). The results of standard statistical calculations for mean direction, mean deviation, and standard deviation are displayed as rose diagrams of data sets (figs. 6-8). To avoid having the analyst or the reader make biased interpretations of inferred stress orientations, rosediagram plots are proportional to petal area, not petal length (Werner, 1976).

In the three areas studied, borehole data from a total of 46 selected wells consisting of 40 well data sets (tables 2-4) were analyzed. Only well data sets having statistical qualities of C or better (table 1) (M.L. Zoback, written commun., 1987) and bimodal-orthogonal and 

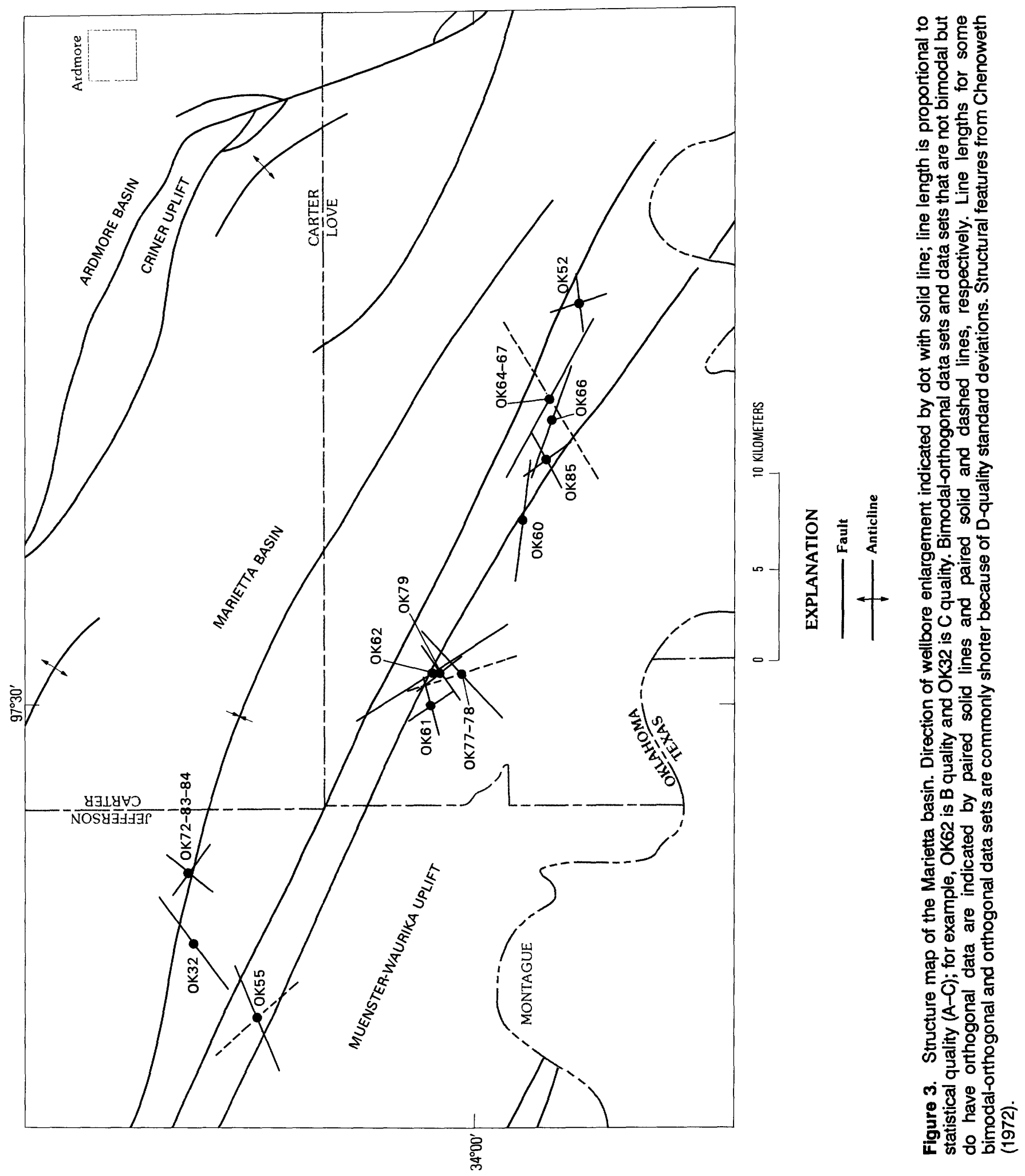


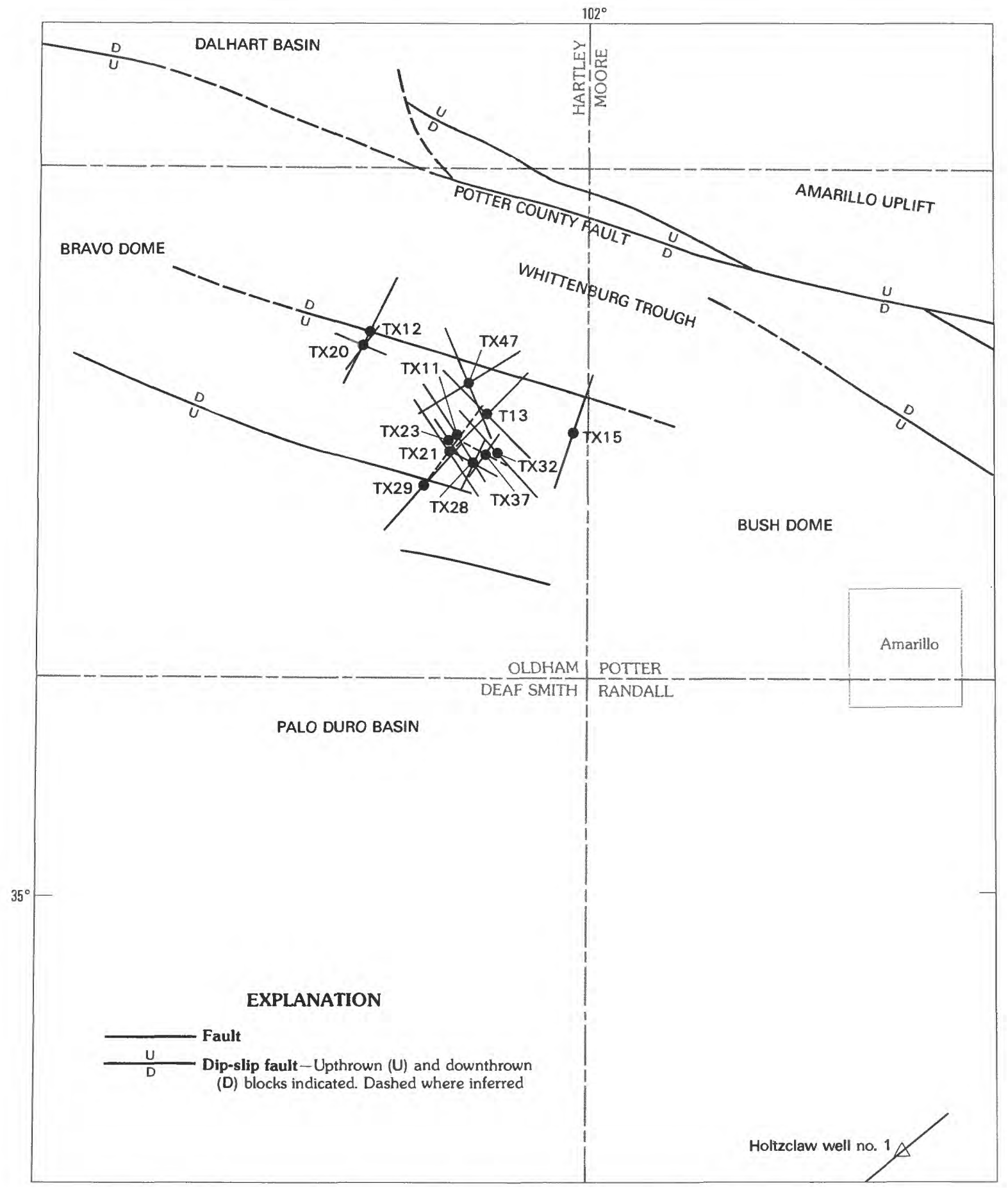

$$
\begin{array}{cccc}
0 & 10 & 20 & 30 \text { KLOMETERS } \\
\hline
\end{array}
$$

Figure 4. Structure map of the Bravo dome area. Direction of wellbore enlargement indicated by dot with solid line; line length is proportional to statistical quality (A-C); for example, TX12 is C quality. Bimodal-orthogonal data sets and data sets that are not bimodal but do have orthogonal data are indicated by paired solid lines and paired solid and dashed lines, respectively. Line lengths for some bimodal-orthogonal and orthogonal data sets commonly are shorter because of D-quality standard deviations. Open triangle with line indicates hydraulic fracturing data (von Schonfeldt and others, 1973). Structural features from McGookey and Goldstein (1982). 


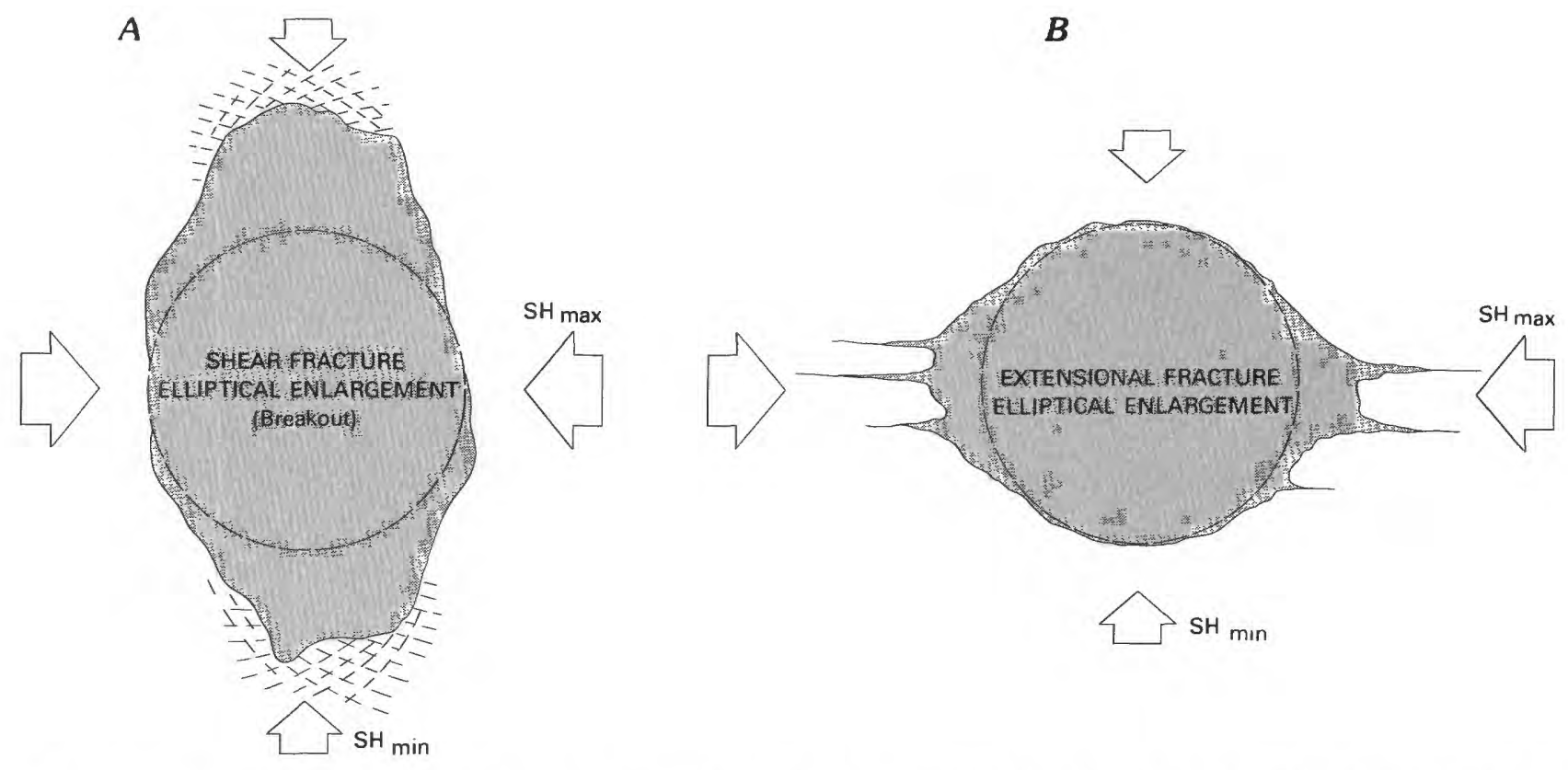

Figure 5. Cross sectional schematics of wellbores showing original borehole shape (dashed line) and enlarged borehole shape (solid line). Breakout $(A)$ and fracture $(B)$ elliptical wellbore enlargements are shown.

orthogonal data sets were used in the statistical calculations of study-area data composites (figs. 6-8, tables $2-4)$. Well locations and calculated mean orientations of the data are plotted in figures 2-4.

Plotted data (figs. 2-4) for individual well data sets consist of four or more wellbore enlargement orientations. Bimodal-orthogonal data sets have orthogonal modes of relatively equal numbers of wellbore enlargement orientations, whereas orthogonal data sets generally have only one wellbore enlargement orientation orthogonal to a preferred (primary) mode of the data. For bimodal-orthogonal data sets, the mean orientations of both modes are plotted as solid lines (figs. 2-4). Preferred modes and orthogonal trends in orthogonal data sets are plotted as solid and dashed lines, respectively.

Breakout data from the 16 well data sets in the eastern Anadarko basin study area form a consistent north-northwest trend. There are no bimodal data sets, and only three of the data sets have minor orthogonal east-northeast trends (fig. 2, table 2). Stress-related fracture wellbore enlargements rarely occur in the eastern Anadarko basin study area.

Common in the Marietta basin and the Bravo dome area are bimodal-orthogonal and orthogonal data sets and well data sets consisting entirely of inferred fracture wellbore enlargements (figs. 3 and 4). In the Marietta basin, 1 of the 12 well data sets consists exclusively of northwest-oriented breakout data, 5 data sets are composed of east-northeast to northeastoriented inferred fracture enlargements, 6 data sets are bimodal-orthogonal, and 3 data sets are orthogonal by definition (table 3). A similar situation was observed in data for the Bravo dome area where of the 12 data sets 3 consist exclusively of breakout data, 3 consist exclusively of inferred fracture wellbore enlargements, 4 are bimodal-orthogonal, and 2 are orthogonal by definition.

\section{ROCK TYPES OF ENLARGEMENT FORMATION}

Probably because of the predominance of carbonate and shale rocks throughout the study region (American Association of Petroleum Geologists, 1983a, b), both breakouts and fracture enlargements are most common in limestone, dolomite, and shale rock units (tables 5 and 6, fig. 9).

In the eastern Anadarko basin, 62 percent of the breakouts and 80 percent of the fracture wellbore

Figure 6 (facing page). Three-dimensional histograms and frequency rose diagrams for the eastern Anadarko basin. Distributions of wellbore enlargements are shown with azimuth $(A)$ versus depth (subsea) and $(B)$ versus frequency of occurrence (feet or number). See text for explanation of statistical values shown. Depths in 1,000-ft increments. Approximate stratigraphic contacts: Upper and Middle Pennsylvanian at $5,500 \mathrm{ft}$; Middle and Lower Pennsylvanian at $7,000 \mathrm{ft}$; Lower Pennsylvanian and top of Mississippian, Devonian, and Silurian at $9,000 \mathrm{ft}$; base of Mississippian, Devonian, Silurian, and Upper Ordovician at $10,200 \mathrm{ft}$; Upper and Middle Ordovician at 10,700 ft; Middle and Lower Ordovician at 11,200 ft; Lower Ordovician and top of Cambrian at $12,500 \mathrm{ft}$; base of Cambrian and top of Precambrian at $13,000 \mathrm{ft}$. 

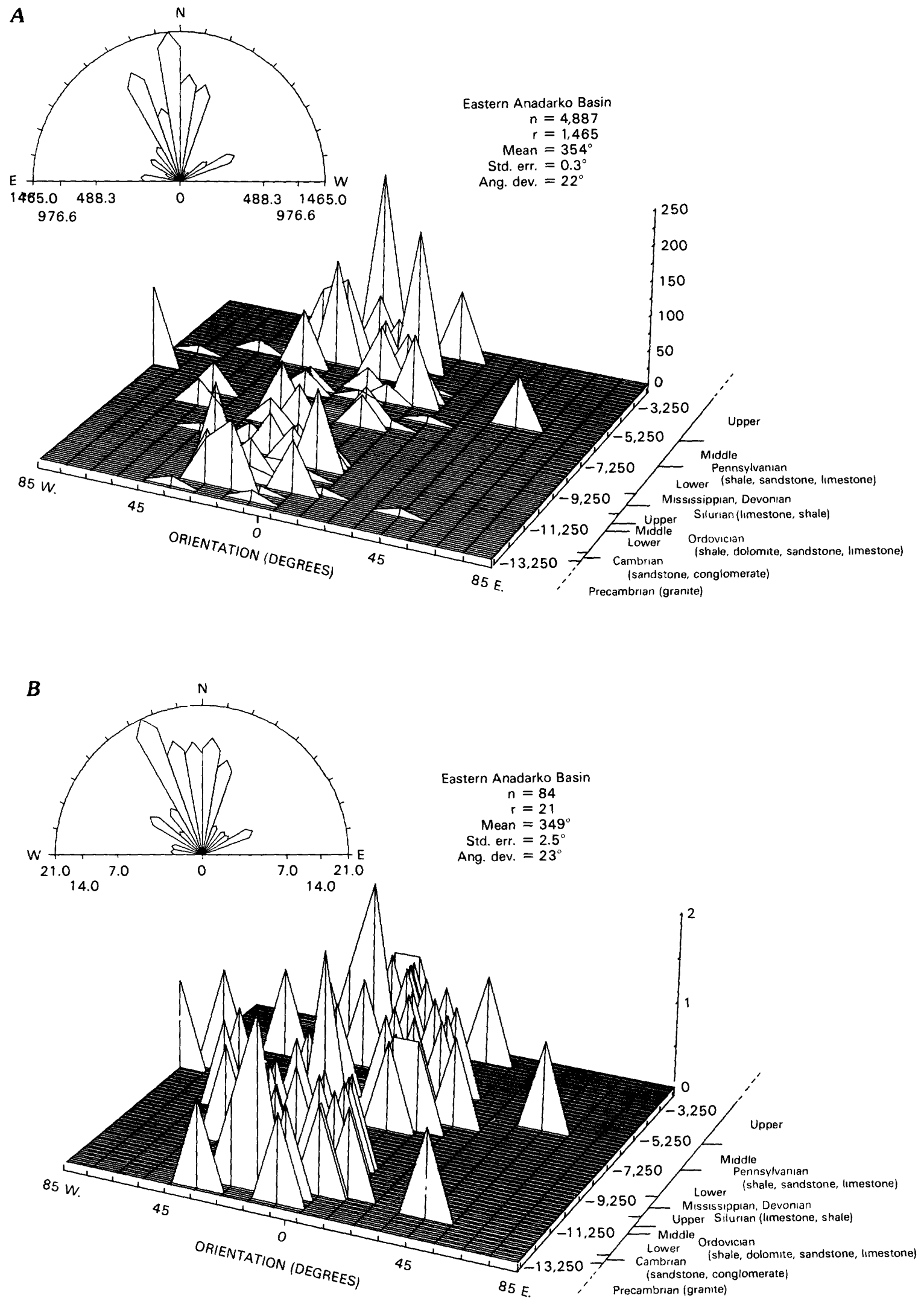

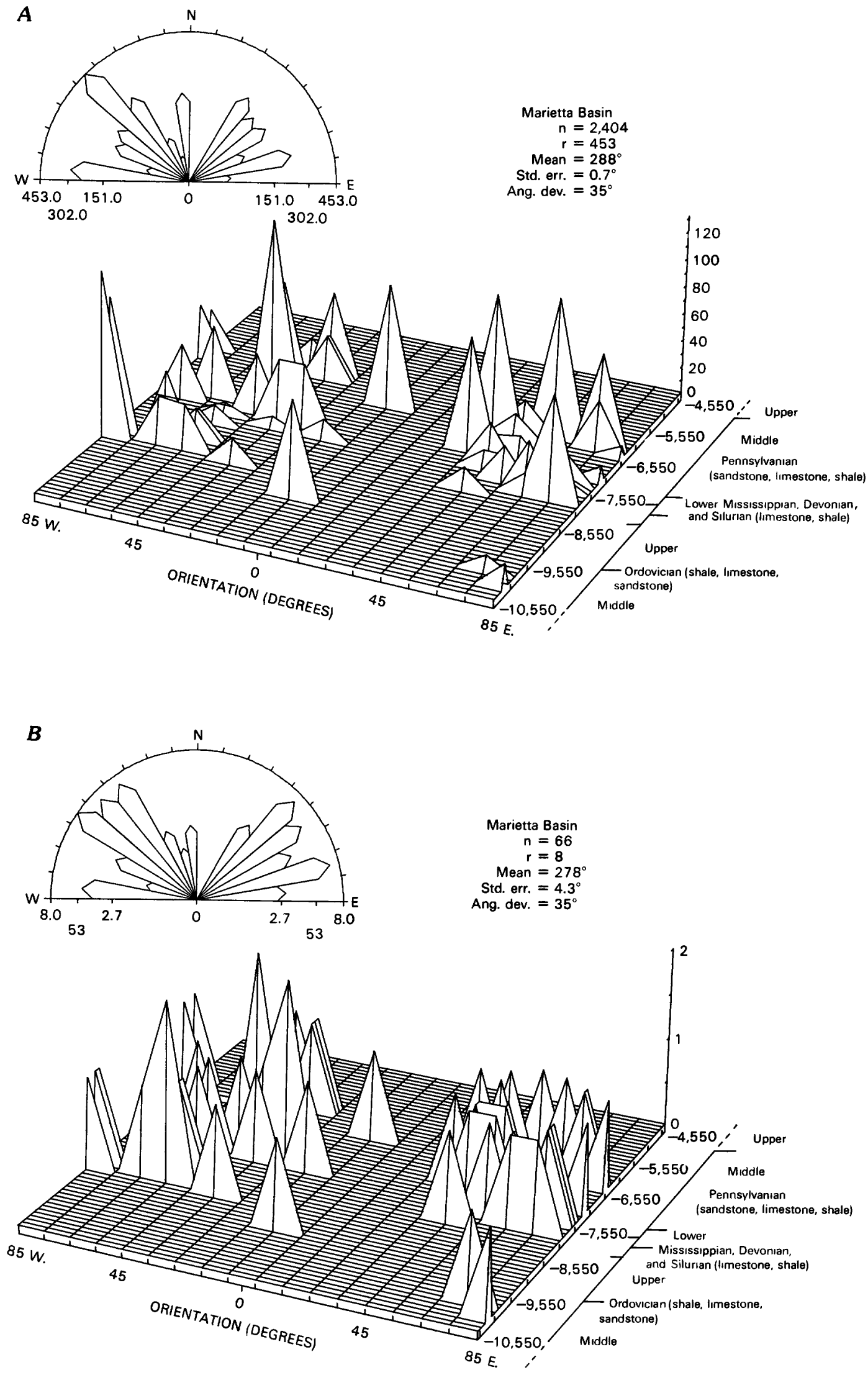
enlargements are in limestone (fig. 9). In the Marietta basin, an equal percentage (43) of both breakout and fracture wellbore enlargements are in limestone (fig. 9). Thirty percent of the breakouts are in formations of sandstone, shale, and limestone, and 27 percent of the fracture enlargements are in shale. In the Bravo dome area, 49 percent of the breakouts and 34 percent of the fracture wellbore enlargements are in dolomite, whereas 35 percent of the breakouts and 43 percent of the fracture enlargements are in shale (fig. 9).

The formation of stress-induced breakouts and stress-related fracture wellbore enlargements in particular rock types are less likely a function of rock type and more probably a function of the abundance of carbonate and shale rocks in the stratigraphic section represented in the dipmeter log records analyzed and the existing in situ stresses within the areas studied. That is, stress conditions necessary to initiate stress-induced and stressrelated wellbore enlargement development probably are present within the dominant sedimentary rock types logged.

\section{FRACTURE ENLARGEMENTS AND DATA SCATTER}

Orthogonal trends in bimodal data sets associated with breakout and fracture-related wellbore enlargement orientations contribute significantly to increased standard deviations for individual well data sets and to the dispersion (data scatter) in data composites for the Marietta basin and Bravo dome study areas (figs. 6-8).

In this study, breakout and fracture-related wellbore enlargements were differentiated by comparing their enlargement orientations with known directions of $\mathrm{SH}_{\max }$ from hydraulic-fracturing measurements (figs. 2 and 4 , table 7). The data suggest that north-northwest to northwest-oriented wellbore enlargements are breakouts and that northeast-oriented wellbore enlargements are fracture-related wellbore enlargements.

Comparison of conductivity values associated with the cross sectional long and short wellbore enlargement axes (short/long axis conductivity ratios) has been

Figure 7 (facing page). Three-dimensional histogram and frequency rose diagrams for the Marietta basin. Distributions of wellbore enlargements are shown with azimuth $(A)$ versus depth (subsea) and $(B)$ versus frequency of occurrence (feet or number). See text for explanation of statistical values shown. Depths are in 500-ft increments. Approximate stratigraphic contacts: Upper and Middle Pennsylvanian at $5,000 \mathrm{ft}$; Middle and Lower Pennsylvanian at 7,500 ft; Lower Pennsylvanian and top of Mississippian, Devonian, and Silurian at 7,700 ft; base of Mississippian, Devonian, Silurian, and Upper Ordovician at 8,300 ft; Upper and Middle Ordovician at $9,000 \mathrm{ft}$. suggested as a possible method of distinguishing breakout from fracture-related wellbore enlargements (Blümling, 1986). This method should work well only when the formation in which the enlargement has formed is of low porosity; that is, favorably oriented preexisting vertical fractures or drilling-induced hydraulic fractures associated with fracture wellbore enlargements may create a more direct path for induced current and thus higher conductivity values (D.G. Davis, oral commun., 1988) than the current path associated with the curvilinear shear failure of breakout wellbore enlargement formation (Dart and Zoback, 1989). In highly fractured or porous rock, dispersion of a directed current should result in lower conductivity values and thus make differentiation of wellbore enlargement type difficult. Detailed information concerning the rock type and porosity of the units in which wellbore enlargements formed is necessary to more accurately differentiate wellbore enlargement type. Greater accuracy in distinguishing between types of wellbore enlargements may be achieved, however, by using digitized dipmeter well logs, which should afford the analyst a greater sampling frequency of conductivity data.

In the areas studied, fracture and joint patterns observed at the surface and at depth agree with orientation trends observed in wellbore enlargement data. A study of subsurface fractures in the "Mississippi Lime" (driller's term) and the Devonian and Silurian Hunton Limestone (9,055-9,331 $\mathrm{ft}$ below ground surface) of Kingfisher County in the eastern Anadarko basin (fig. 2) reveals a bimodal pattern of vertical natural fractures (Brevetti and others, 1984): a primary north-south trend and a secondary east-west trend. These fractures are within the depth interval for breakout occurrence. The mean orientations of both fracture trends are subparallel with the mean orientations of breakouts and with the minor set of orthogonally oriented wellbore enlargements inferred to be fracture related.

In the Slick Hills area of Oklahoma, adjacent to and north of the Meers fault in the southwest corner of the eastern Anadarko basin (fig. 2) and approximately $70 \mathrm{~km}$ northwest of the Marietta basin, Wilhelm and Morgan (1986) observed a bimodal pattern of geographic lineaments oriented between N. $30^{\circ}-60^{\circ} \mathrm{W}$. and N. $40^{\circ}-50^{\circ} \mathrm{E}$. These "well-constrained" lineament patterns are interpreted as being associated with northweststriking left-lateral and high-angle thrust faults and northeast-striking right-lateral faults (Wilhelm and Morgan, 1986). This bimodal pattern agrees with the mean orientations of breakouts and orthogonally oriented, inferred fracture-related wellbore enlargements from wells in the Marietta basin (fig. 3).

In the Bravo dome area of the Texas Panhandle (fig. 4), surface and subsurface fractures also form bimodal trends oriented roughly west-northwest and 


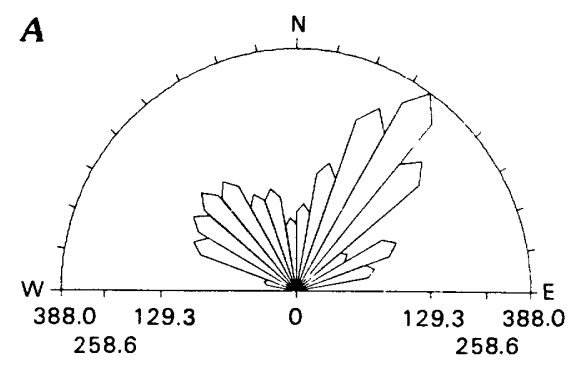

Bravo Dome Area

$n=1,851$
$r=388$

Mean $=23$

Std. err. $=0.8^{\circ}$

Ang. dev. $=33^{\circ}$

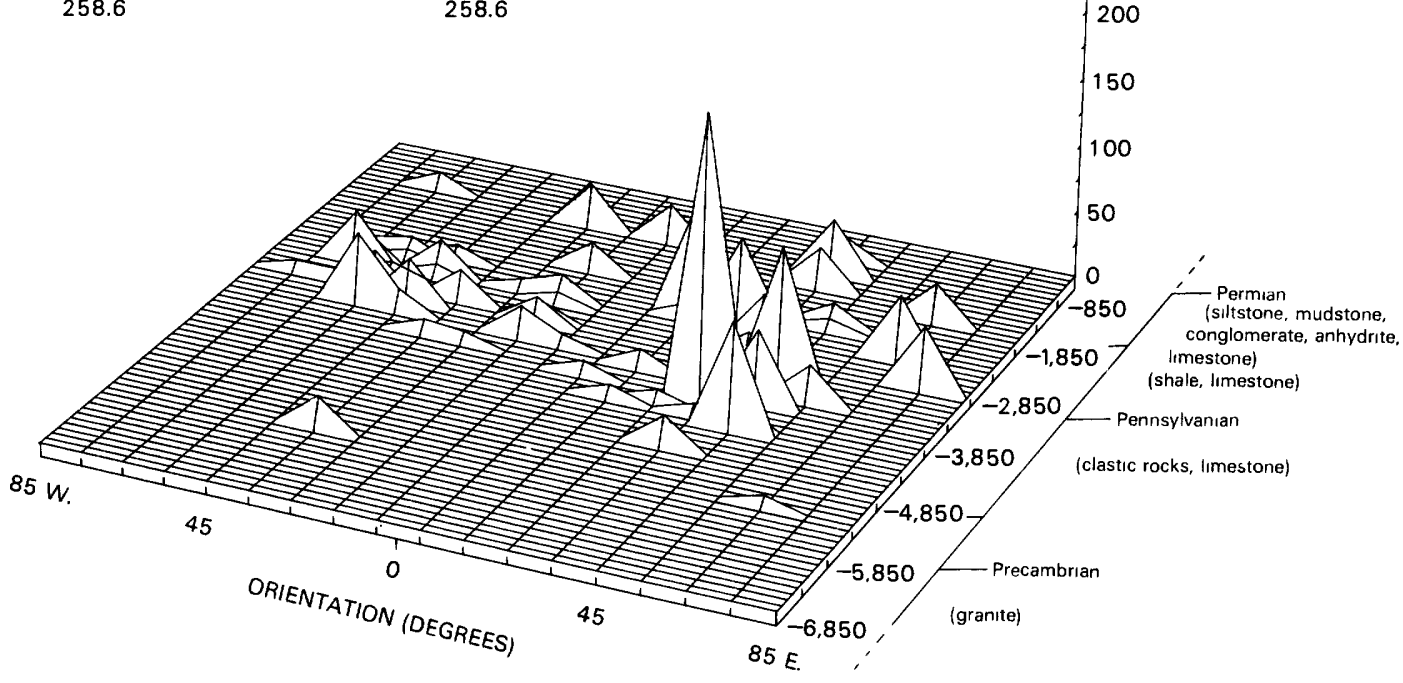

B

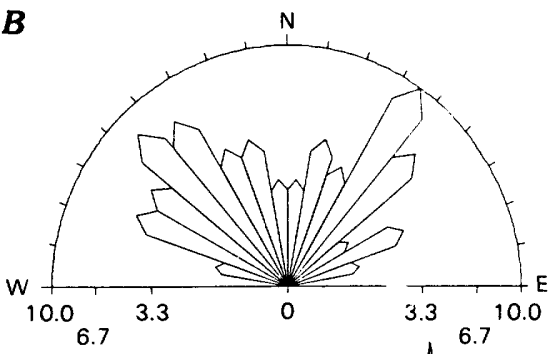

Bravo Dome Area $n=66$
$r=10$

Mean $=348^{\circ}$

Std. err. $=4.5^{\circ}$

Ang. dev. $=36^{\circ}$

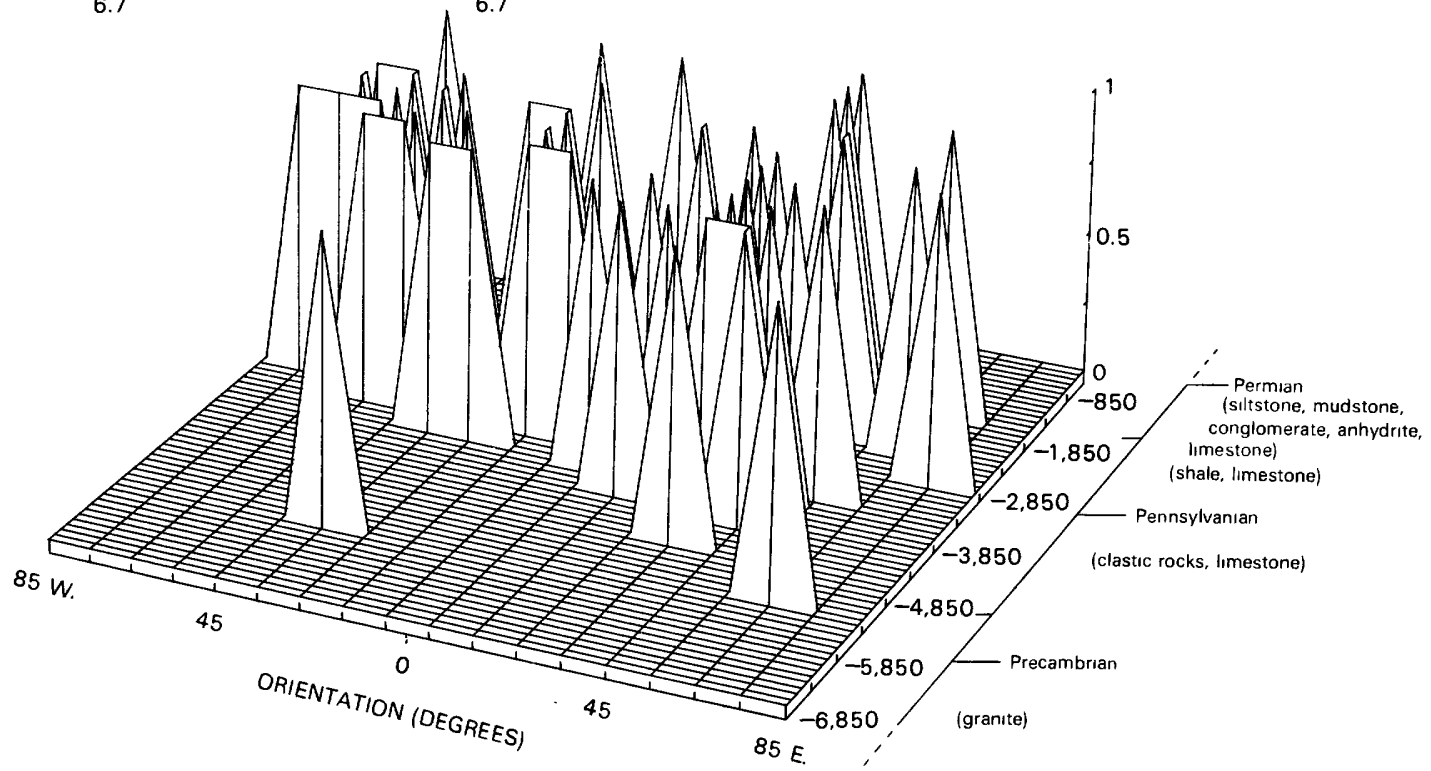


Table 1. Quality criteria for breakout (wellbore enlargement) data

[A breakout data set is considered very poor (VP) if its standard deviation is greater than $30^{\circ}$, regardless of the number of breakouts measured. Leaders (--) indicate any number of breakouts. Table from M.L. Zoback (written commun., 1987)]

\begin{tabular}{ccc}
\hline $\begin{array}{c}\text { Data set } \\
\text { quality }\end{array}$ & $\begin{array}{c}\text { Number of } \\
\text { breakouts }\end{array}$ & $\begin{array}{c}\text { Angular } \\
\text { deviation }\end{array}$ \\
\hline A & $\geq 10$ & $\leq 12^{\circ}$ \\
B & $\geq 6$ & $>12^{\circ}, \leq 20^{\circ}$ \\
C & $\geq 4$ & $>20^{\circ}, \leq 25^{\circ}$ \\
D & $<4$ & $>25^{\circ}, \leq 30^{\circ}$ \\
VP & --- & $>30^{\circ}$ \\
\hline
\end{tabular}

northeast (Gustavson and Budnik, 1985; Gustavson and Finley, 1985). Although the bimodal trends of these fractures are somewhat random, agreement does exist between the bimodal trends of subsurface near-vertical fractures (Gustavson and Budnik, 1985) observed in the Stone and Webster Holtzclaw No. 1 well (fig. 4) and northwest- and northeast-oriented wellbore enlargements in the Bravo dome area.

In all three study areas, the mean orientations of breakouts and inferred fracture wellbore enlargements are about the same as bimodal orientations of observed natural fractures within or adjacent to these areas. This finding tends to support a genetic relationship between the formation of some wellbore enlargements and preexisting vertical fractures.

Studies show that drilling-induced hydraulic fracturing is related to an increase in hydrostatic pressure within the wellbore or to a decrease in rock tensile strength (Ellis and Swolfs, 1983; Stock and others, 1985). Unfortunately, an association between hydraulic fracturing and the formation of inferred fracture wellbore enlargements could not be verified for the study areas due to the unavailability of detailed drilling records of pumping pressures and fluid weights; however, changes in relative conductivity on dipmeter logs do show the coincidence of wellbore enlargements and formational or bedding boundaries.

A possible mechanism for the development of fracture-related enlargements of either type involves the "chipping out" of the wellbore during the drilling process (D.G. Davis, oral commun., 1988). By this means, the wellbore is enlarged elliptically in an area weakened by

Figure 8 (facing page). Three-dimensional histogram and frequency rose diagrams for the Bravo dome area. Distributions of wellbore enlargements are shown with azimuth $(A)$ versus depth (subsea) and $(B)$ versus frequency of occurrence (feet or number). Clastic rocks are granite wash. See text for explanation of statistical values shown. Depths are in 500-ft increments. Approximate stratigraphic contacts: Permian and Pennsylvanian at $1,700 \mathrm{ft}$; Pennsylvanian and Precambrian at $5,000 \mathrm{ft}$. drilling-induced hydraulic fractures or by favorably oriented, open, preexisting vertical natural fractures or joint sets intersecting the borehole. The process of fracture-related enlargement formation may be aided by the erosional effects of circulating drilling fluid and drill-string wear.

Due to the difference in horizontal stress concentrations about the borehole, favorably oriented preexisting vertical fractures intersecting the wellbore should remain open and thus increase the possibility of mechanical wellbore enlargement. A possible example of this process is given by Gustavson and Budnik (1985) in their discussion of the preferred northeast orientation of fracture-related solution features in the Permian saltbearing stratigraphy of the Texas Panhandle and northeast-oriented hydraulic fractures induced in the Stone and Webster Holtzclaw No. 1 well (fig. 4). Gustavson and Budnik postulated that dissolution of saltbearing formations was more rapid in the direction of $\mathrm{SH}_{\max }$ along northeast-oriented fractures.

Fractures intersecting the wellbore do not always develop wellbore enlargements. Eighty-four fractures observed as conductive anomalies on fracture identification logs from six Marietta basin wells (The Anchutz Corporation, unpub. data, 1987) exhibit very few wellbore enlargements. These 84 fractures, having a mean azimuth of $\mathrm{N} .42^{\circ} \mathrm{E}$. and primarily in the Upper Ordovician Viola Limestone, were compared with 35 northeastoriented wellbore enlargements from 13 additional wells in the same basin. Many of the 35 northeast-oriented wellbore enlargements, inferred to be fracture related, are in limestone and shale formations and are associated with fracture-conductivity anomalies. These 35 wellbore enlargements have an average orientation of $\mathrm{N} .65^{\circ} \mathrm{E}$. The $27^{\circ}$ difference in orientation between these two groups of data may be due in part to variations in natural fracture orientation, spacing, and dip or to the variation between present-day and paleostress orientations.

Preexisting fractures intersecting the borehole at azimuths parallel or subparallel with the $\mathrm{SH}_{\mathrm{min}}$ direction may also contribute to development of stress-induced breakouts. This appears to be the case for at least one wellbore enlargement in the eastern Anadarko basin, well OK16 (fig. 2). This wellbore enlargement is associated with a conductivity anomaly indicative of fracturing but is oriented in the direction inferred for breakouts. This situation is not interpreted to be a $90^{\circ}$ rotation of the stress field but rather the formation of a stressinduced breakout within an interval of the wellbore weakened by preexisting northwest-oriented vertical fracturing or jointing.

An increase in the difference in horizontal stress magnitudes associated with gravitational loading, rock properties, and bedding thickness (Amadei and others, 1988) may also contribute to the formation of fracture 


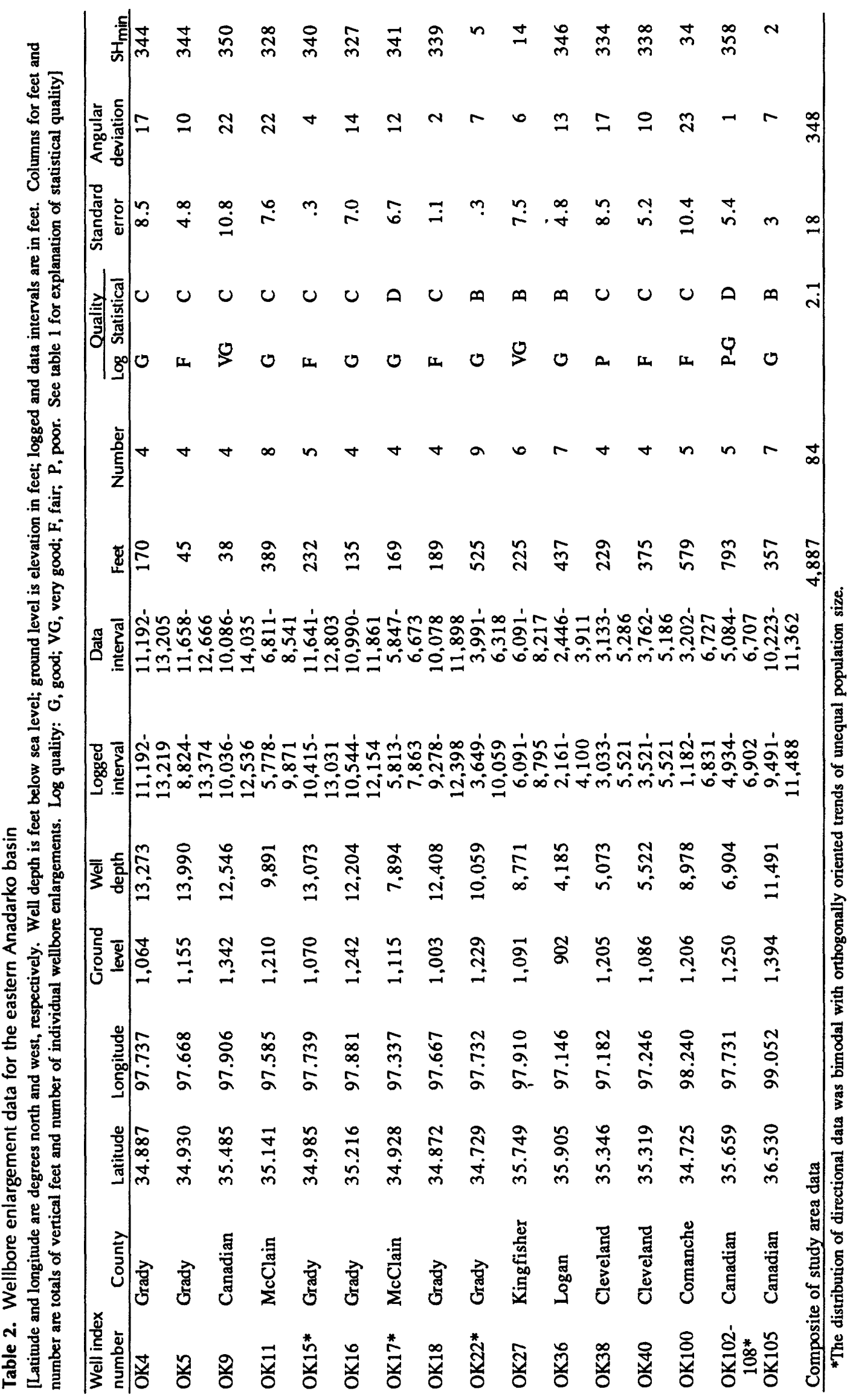




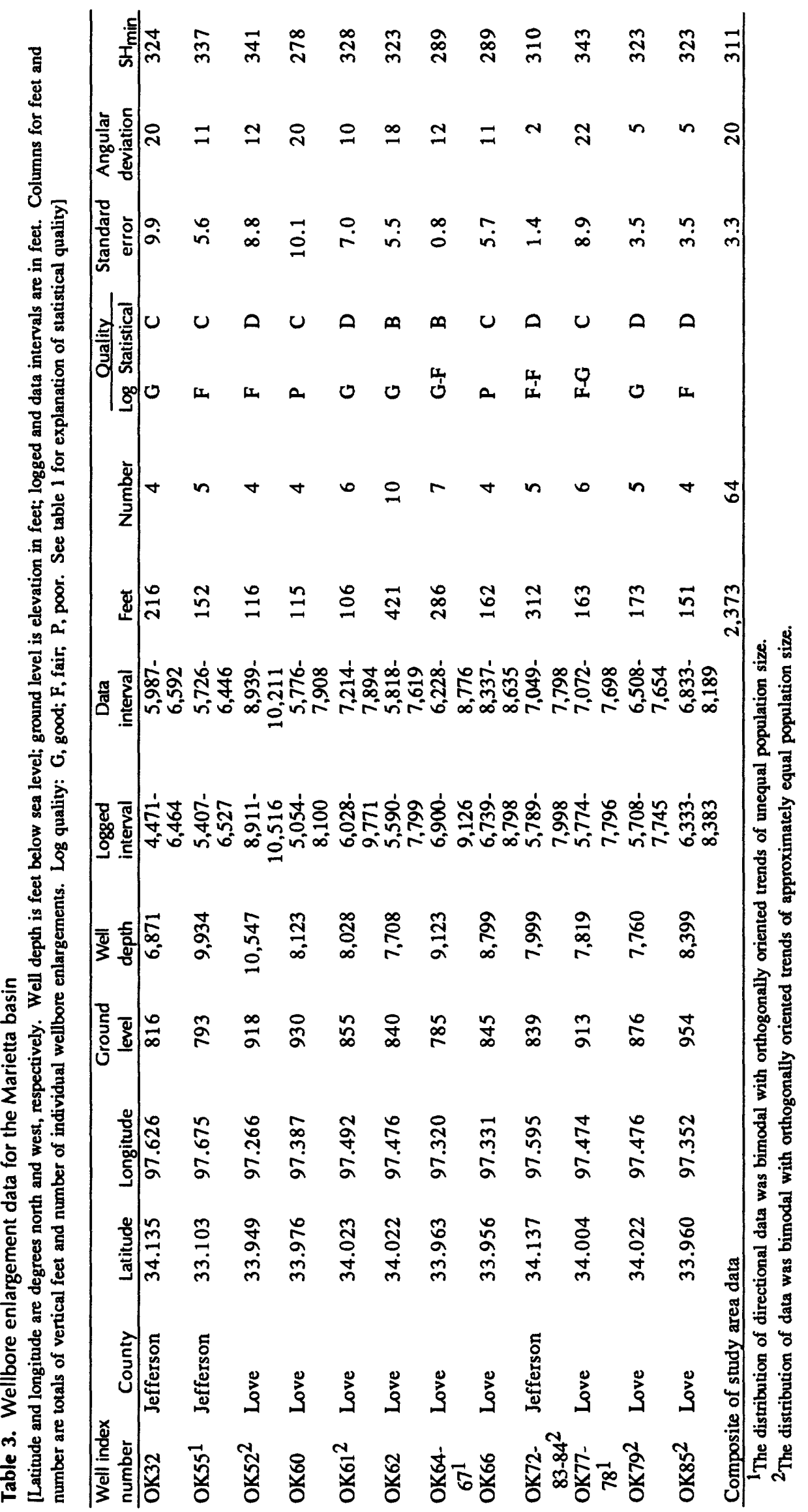




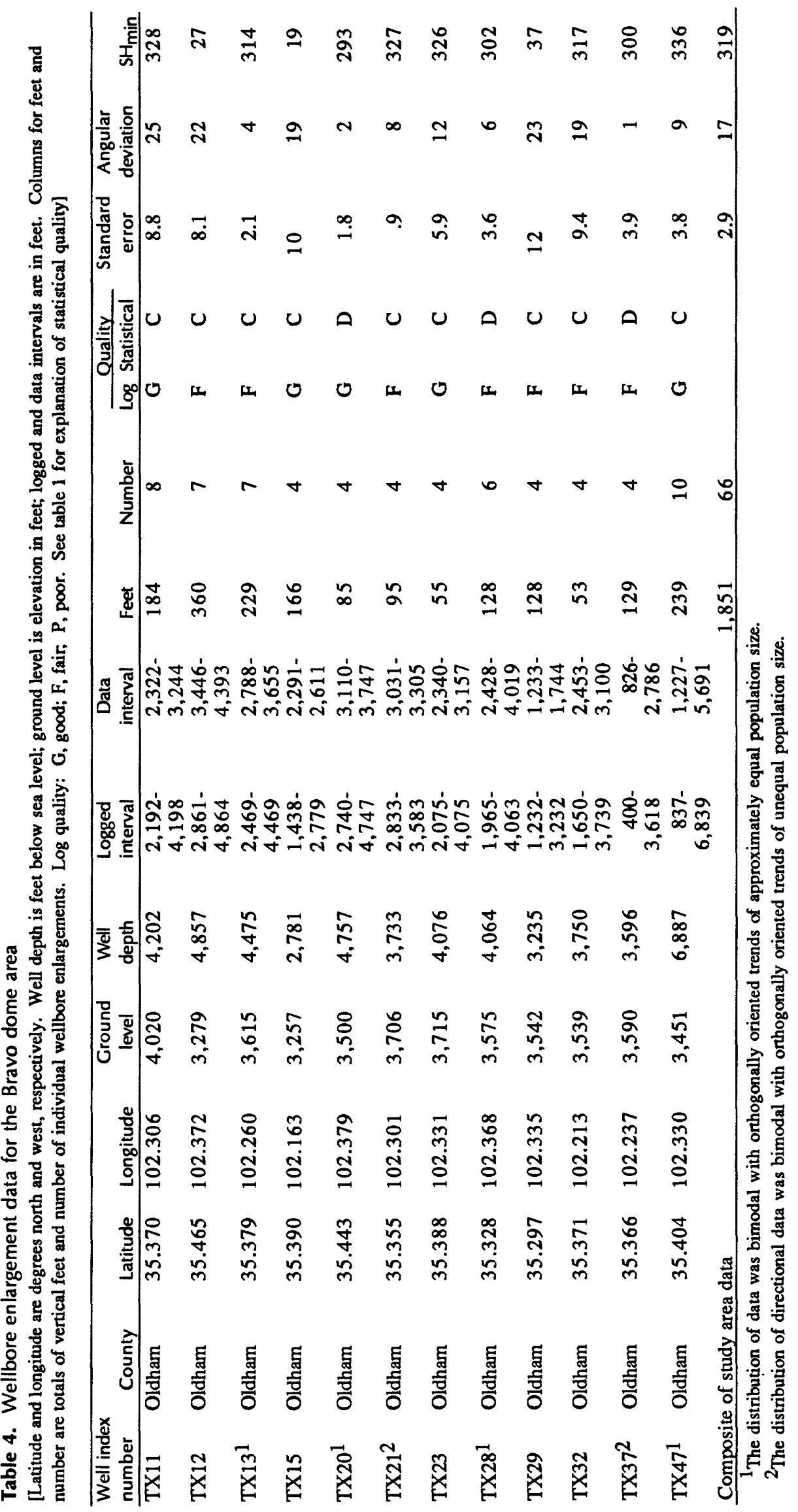


wellbore enlargements in the study areas . Amadei and others proposed a model of gravity-induced variation in stress magnitudes in anisotropic, stratified rock masses by treating layered strata as finite mechanical units. This model predicts that induced components of horizontal stress can vary in magnitude between rock units, either less or more than the vertical stress.

Formation of randomly oriented wellbore enlargements associated with lower confining pressures at shallow depths (Dart, 1987; Springer, 1987) can generally be ruled out as a contributor to data scatter because near-surface $(<1,000 \mathrm{ft}$ subsea) wellbore enlargements are commonly washed out and enlarged in both orthogonal directions. These data were not considered reliable and were not used.

Small differences in horizontal-stress magnitudes (Springer, 1987), as measured in the Stone and Webster Holtzclaw No. 1 well (fig. 4), may contribute to dispersion among enlargement orientations in the Bravo dome area. This cannot be said, however, for the eastern Anadarko and Marietta basins because in situ measurements of horizontal stress magnitudes are not available.

The observed randomness in wellbore enlargement orientations in the Marietta basin and Bravo dome areas is not thought to be related to a large horizontal stress ratio and variation in borehole shape (Morin and others, in press). Large horizontal stress differences were not observed in the Stone and Webster Holtzclaw No. 1 well (Stone and Webster Engineering Corporation, 1983), and the aseismicity of the study region (fig. 1) (Stone and Webster Engineering Corporation, 1983) suggests a small difference in regional horizontal stresses.

\section{INFERRED STRESS DIRECTIONS AND RELATIVE STRESS MAGNITUDES}

Directions of $\mathrm{SH}_{\max }$ calculated from stress measurements (table 7) agree with directions of $\mathrm{SH}_{\max }$ inferred from breakout data (table 8) in the study region. The average direction of $\mathrm{SH}_{\max }$ inferred from hydraulicfracturing measurements for the region (fig. 1) is N. $50^{\circ}$ $\mathrm{E}$, and the average direction of $\mathrm{SH}_{\max }$ inferred from breakout data for the three study areas is N. $56^{\circ} \mathrm{E}$.

The relative magnitudes of $S_{1}, S_{2}$, and $S_{3}$ within the study region can be evaluated from available hydraulicfracturing data, evidence of recent faulting, and the frequency of breakout occurrence with depth. Values of $\mathrm{S}_{\mathrm{v}} \mathrm{SH}_{\mathrm{min}}$, and $\mathrm{SH}_{\max }$ magnitudes from hydraulicfracturing measurements exist for one well (Stone and Webster Holtzclaw No. 1) within the study region (fig. 2, table 7). The relationship of principal stress magnitudes from the Stone and Webster Holtzclaw well No. 1 (fig. 4), located $80 \mathrm{~km}$ southeast of the Bravo dome area in the Palo Duro basin, is

$$
\mathrm{S}_{1}>\mathrm{S}_{2}>\mathrm{S}_{3} \text {, or } \mathrm{S}_{\mathrm{v}}>\mathrm{SH}_{\max }>\mathrm{SH}_{\mathrm{min}} \text {, or } \mathrm{S}_{\mathrm{v}}>\mathrm{S}_{\mathrm{NE}}>\mathrm{S}_{\mathrm{NW}} \text {. }
$$

The ratio of $\mathrm{S}_{\mathrm{v}}$ to $\mathrm{SH}_{\max }$ is 1.19 and the ratio of $\mathrm{SH}_{\max }$ to $\mathrm{SH}_{\mathrm{min}}$ is 1.28 for siltstone and limestone formations (table 7). Stresses measured for intervening salt formations deviate from this stress relationship. Because salt is an elastoplastic rock, stresses measured in salt formations are not considered reliable indicators of the regional stress field (Borjeson and Lamb, 1988).

In the Arbuckle uplift (fig. 1), surface overcoring stress measurements (table 7) are an unreliable indication of stress conditions within the region because of the domed structure of this igneous body (H.S. Swolfs, oral commun., 1988). Breakout stress data from the vicinity of the Arbuckle uplift agree only generally with stress directions calculated from the overcoring measurements in this area.

Stress-magnitude calculations using mini-frac (H.S. Swolfs, oral commun., 1988) and leak-off test data (Ervine and Bell, 1987) could not be made for the three study areas because these types of borehole pressure test data are not available.

Relative horizontal stress differences may be approximately inferred by examining the frequency of breakout occurrence with depth. Initiation of shearfailure spalling and rate of breakout development probably are controlled by the horizontal stress difference about the wellbore and the confining strength of the rock (Mastin, 1984; Haimson and Herrick, 1985; Zoback and others, 1985). Assuming that the fracture gradient, the pressure per unit depth required to fracture or cause the rock to separate (Society of Professional Well Log Analysts, 1984), and the magnitudes of $S_{1}, S_{2}$, and $S_{3}$ all increase at their respective rates with depth, the following conditions are likely true: (1) when breakouts do not occur or are random in orientation, $\mathrm{SH}_{\max } \simeq \mathrm{SH}_{\mathrm{m} \text { in }}$; (2) when breakouts do occur, $\mathrm{SH}_{\max } / \mathrm{SH}_{\min }>1$ (Zoback and others, 1985); (3) when the frequency of breakout occurrence increases with depth, the horizontal stress difference increases with depth (because the fracture gradient is also assumed to be increasing with depth but at a slower rate); (4) when the frequency of breakout occurrence remains about the same with depth, the horizontal stress difference is probably constant; and (5) when the frequency of breakout occurrence decreases with depth, the horizontal stress difference may decrease with depth or increase at a slower rate than the increase in the fracture gradient. Thus, breakout occurrence and the extent of breakout development in any given area is likely associated with the rates at which in situ stresses change with depth.

In a seismically active area where $S_{1}$ is horizontal, such as the New Madrid area of the Mississippi Embay- 

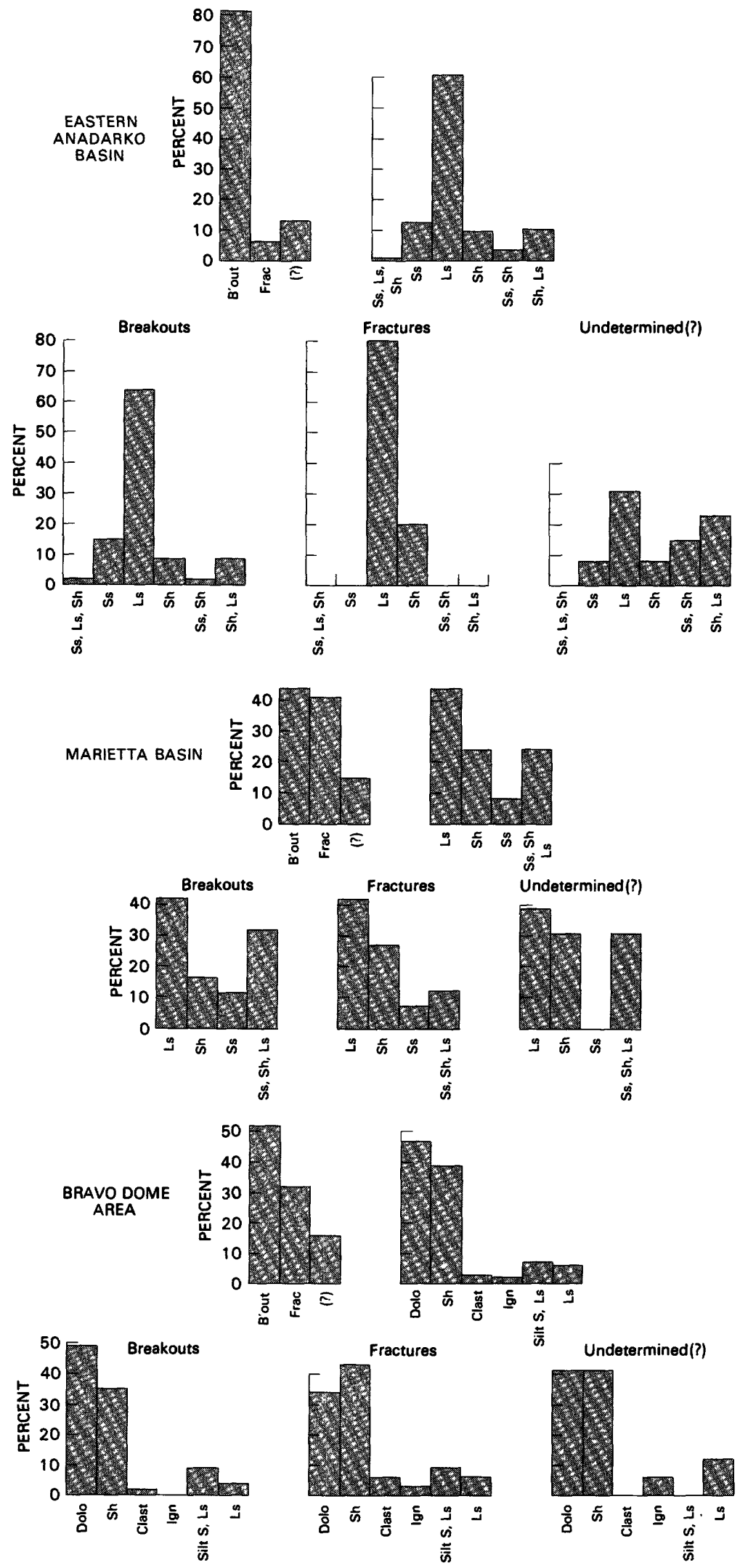
ment (Zoback and Zoback, 1980), stress-induced wellbore enlargements from two wells (Dart, 1987) appear to be of greater vertical length (table 9) and have a distinct, characteristic shape (as seen on the dipmeter log). In contrast, in a relatively aseismic area such as the Palo Duro basin (Stone and Webster Corporation, 1983), where $S_{1}$ is vertical and where in the near surface $S_{2}$ may not be significantly greater than $S_{3}$ (table 7)(Borjeson and Lamb, 1987), wellbore enlargements in nearby wells (Bravo dome area), on average, appear to have shorter vertical lengths (table 9) and less well defined trace character on the dipmeter $\log$ (log quality on table 4$)$. If wellbore enlargements are compared for areas having different levels of seismic activity but with similar sedimentary rock types, as is probably the case for the New Madrid seismic zone and the Bravo dome area, wellbore enlargement length and frequency of occurrence are likely a function of the horizontal stress difference.

Figures $6-8$ illustrate the relationship of wellbore enlargement vertical length and frequency of occurrence to depth. For the eastern Anadarko basin data (fig. 6), frequency of breakout occurrence (number) does not decrease with depth for the logged interval $(-3,000$ $\sim 13,000 \mathrm{ft}$ ); however, breakout length does decrease with depth (fig. 6). This decrease is expected given the longer time period during which breakouts can develop in the upper part of the borehole and the subsequent longer exposure time to drill-string wear. Although the marked decrease in breakout occurrence between depths of about 6,000 and $9,000 \mathrm{ft}$ (fig. 6) cannot be accounted for, it may be the result of an increase in rock tensile strength or a decrease in the ratio of horizontal stresses within this interval of Middle Pennsylvanian (Desmoinesian and Atokan) and Lower Pennsylvanian (Morrowan and Springeran) formations.

In the Marietta basin (fig. 7), both breakouts and fracture wellbore enlargements occur at approximately the same frequency with depth. The fact that they seem to terminate at about $9,000 \mathrm{ft}$ may be related to the small number of wells (three) that were logged below this depth. In the Marietta basin data, scatter among breakout orientations contrasts with the tight grouping of northeast-oriented fracture-related wellbore enlargements. This contrast may be a function of the ratios of principal stresses in situ. A decrease in the ratio of

Figure 9 (facing page). Vertical bar graphs of wellbore enlargement type and rock type of enlargement occurrence for the eastern Anadarko basin, Marietta basin, and Bravo dome study areas. Bars represent percentages of the total data set for each study area. Enlargement types: B'out, breakout; Frac, fracture; (?), undetermined. Rock types: Sh, shale; Ss, sandstone; Ls, limestone; Dolo, dolomite; Silt S, siltstone; Ign, igneous; Clast, clastic. horizontal stresses in the Marietta basin may contribute to scatter among breakout orientations, whereas an increase in the ratio of $\mathrm{S}_{\mathrm{v}}$ to $\mathrm{SH}_{\mathrm{max}}$ may contribute to drilling-induced hydraulic fracturing of the wellbore and the formation of fracture enlargements. In normalfaulting stress regimes where $S_{1}$ is vertical, drillinginduced hydraulic fracturing is more likely to occur than in compressive stress regimes where $S_{1}$ is horizontal (Healy and others, 1984; Stock and others, 1985).

Breakout and fracture wellbore enlargements occur with depth at approximately the same frequency (number) in the Bravo dome area data (fig. 8). Fracture enlargements have longer vertical lengths than breakouts and, as in the Marietta basin data, form a tighter grouping of northeast-oriented fracture-related wellbore enlargements than northwest-oriented breakout wellbore enlargements (fig. 8). Neither breakouts nor fracture-related wellbore enlargements occur below $5,750 \mathrm{ft}$. Only 1 of the 12 well data sets had a logged interval extending below this depth. In the logging interval above $5,750 \mathrm{ft}$, both breakout and fracture wellbore enlargement development decrease with depth. Very few wellbore enlargements of either type occur within the 1,500-ft interval between 4,250 and $7,500 \mathrm{ft}$ (fig. 8). This apparent decrease in wellbore enlargement development below $4,250 \mathrm{ft}$ may indicate changing stress ratios $\left(\mathrm{S}_{\mathrm{v}} / \mathrm{SH}_{\max }\right.$ and $\left.\mathrm{SH}_{\max } / \mathrm{SH}_{\min }\right)$ with depth. The tight grouping of well-developed fracture-related enlargements in the Bravo dome area data may indicate a normal-faulting stress regime. Hydraulic-fracturing measurements of $S_{1}, S_{2}$, and $S_{3}$ from the Stone and Webster Holtzclaw No. 1 well in the northern Palo Duro basin (fig. 4) confirm that this part of the Texas Panhandle (fig. 1) is a normal-faulting stress regime.

Several important observations can be made concerning the state of stress within the study region.

1. Strike-slip and reverse-fault movement on the Meers fault (fig. 2) and possible displacement on other west-northwest-oriented faults in the Frontal fault system of southern Oklahoma are inconsistent with a normal-faulting stress regime indicated for the Texas Panhandle.

2. Hydraulic-fracturing measurements in the Stone and Webster Holtzclaw No. 1 well (fig. 4, table 6) were made at shallow depths $(1,854-2,794 \mathrm{ft}$ below ground surface). The ratios of $\mathrm{S}_{\mathrm{v}} / \mathrm{SH}_{\max }$ and $\mathrm{SH}_{\max } /$ $\mathrm{SH}_{\mathrm{min}}$ are close to 1.0. The difference in $\mathbf{S H}_{\max }$ and $\mathrm{SH}_{\mathrm{m} \text { in }}$ magnitudes increases with depth, whereas the difference in $\mathrm{S}_{\mathrm{V}}$ and $\mathrm{SH}_{\max }$ magnitudes decreases with depth. The ratios of stresses may be different at depth than they are near the surface.

3. The Bravo dome and northern Palo Duro basin areas lie on or very near the boundary between the southern Great Plains and Midcontinent stress provinces. The states of stress for these two provinces are 


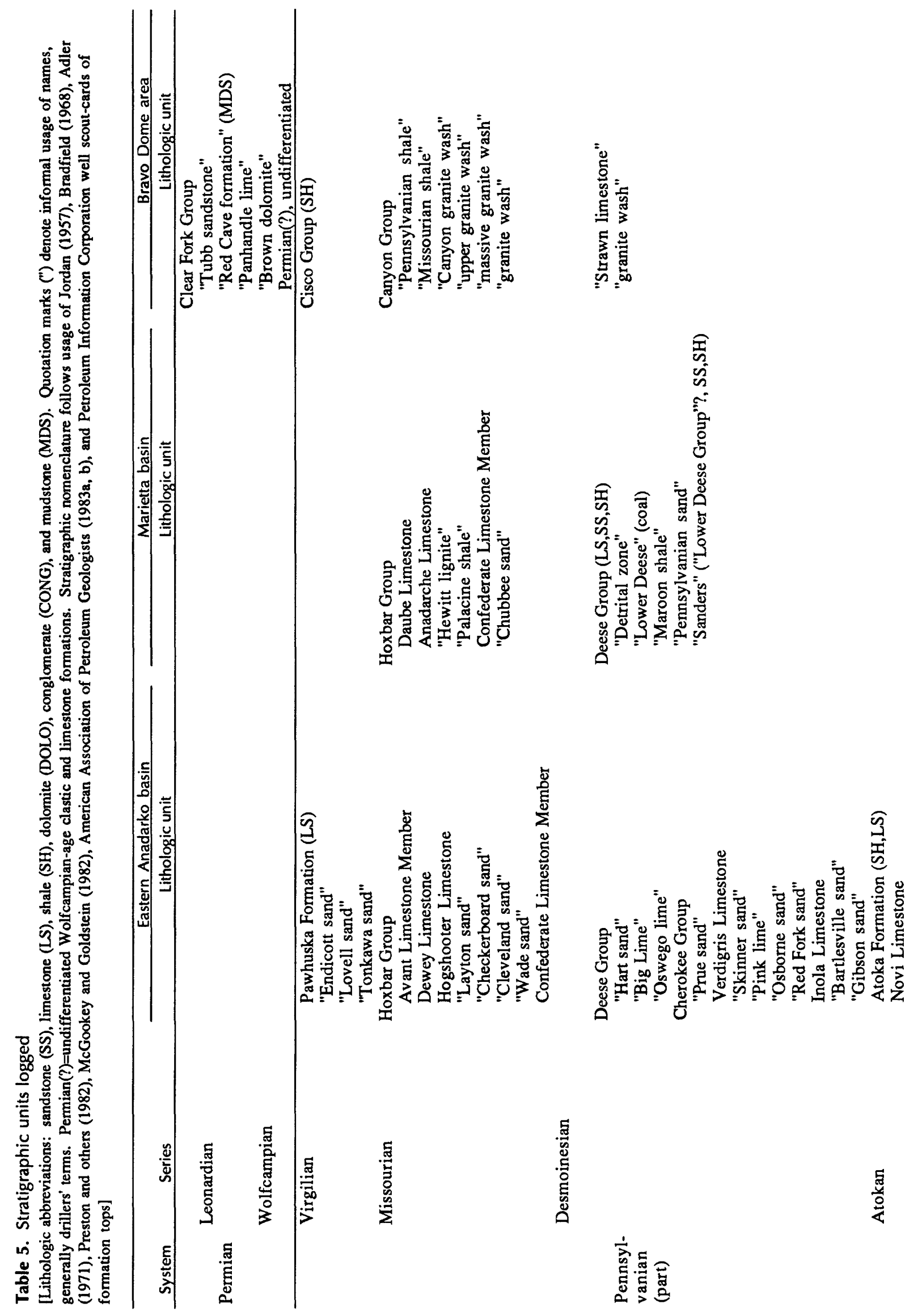




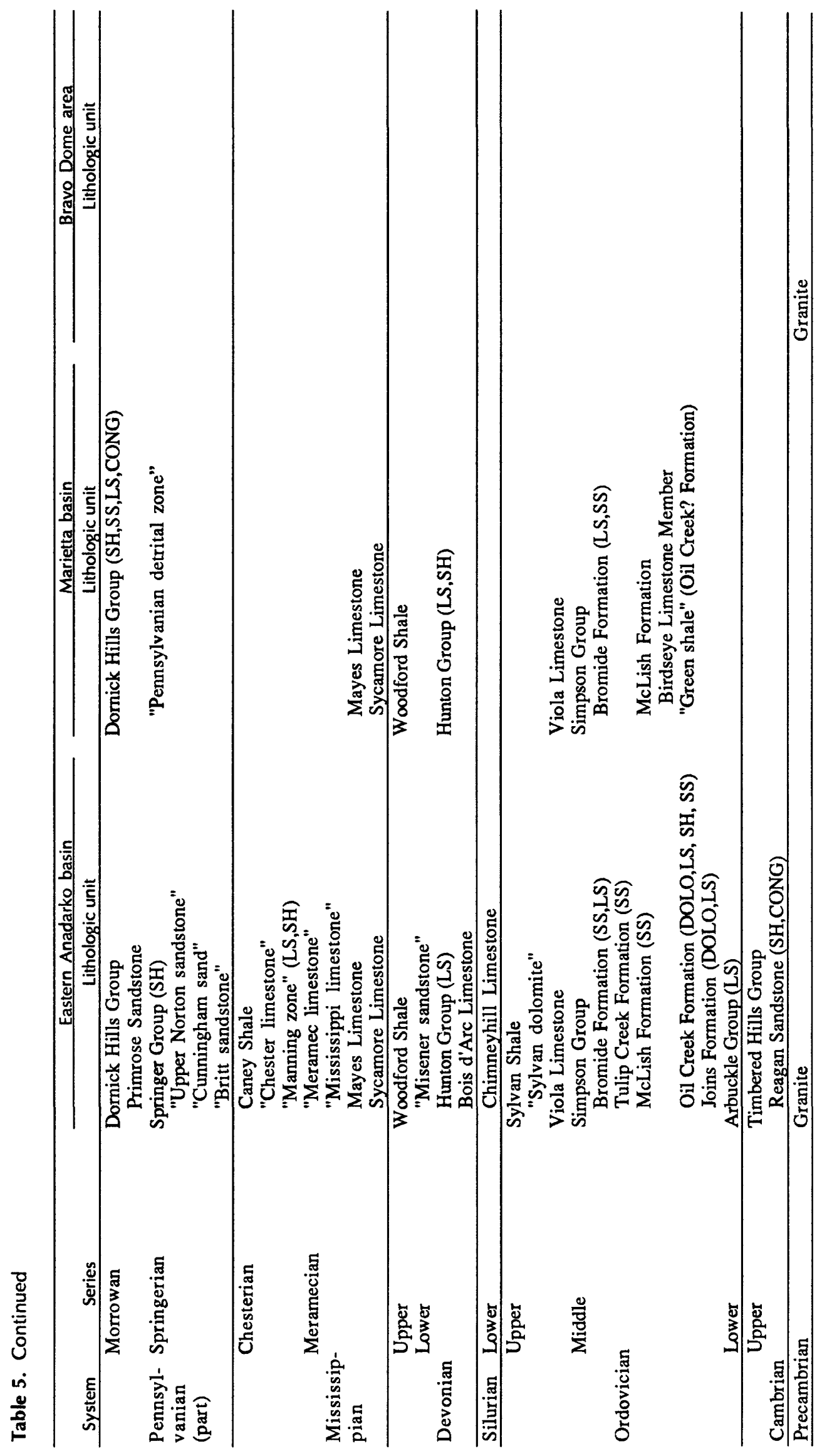


Table 6. Wellbore enlargement type, frequency of occurrence, and orientation

[Azimuth (in degrees) is the median for every $10^{\circ}$ interval between $90^{\circ} \mathrm{W}$. and $90^{\circ} \mathrm{E}$. Wellbore enlargement type and frequency are shown. Type: B, breakout; F, fracture; asterisk (*), uncertain. Frequency of occurrence is the number of discrete wellbore enlargement intervals. Quotation marks indicate informal usage of names. Permian (?) indicates undifferentiated Wolfcampian-age clastic and limestone formations]

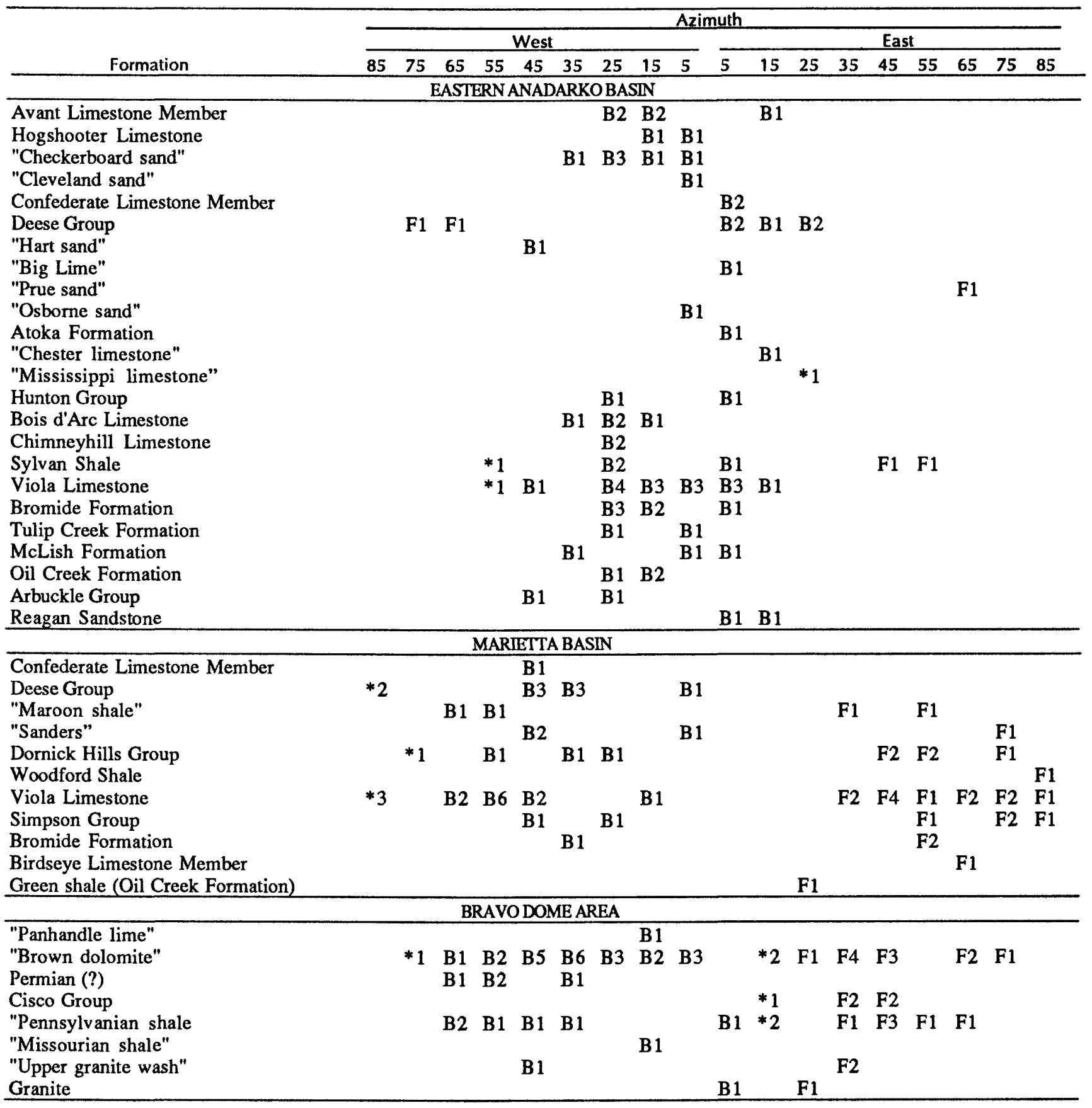

interpreted as being opposite (Zoback and Zoback, 1980 ). The southern Great Plains stress province is a region of extensional tectonics with $\mathrm{SH}_{\mathrm{m} \text { in }}=\mathrm{S}_{\mathrm{NNE}}$, whereas the Midcontinent stress province is a region of compressional tectonics with $\mathrm{SH}_{\mathrm{max}}=\mathrm{S}_{\mathrm{NE}}$ (Zoback and Zoback, 1980). Therefore, near-surface stress conditions in the Bravo dome area may deviate from those farther east within the Midcontinent stress province.
4. In view of available hydraulic-fracturing data (table 7) and the apparent recent strike-slip and reverse movement on the Meers fault (Ramelli and others, 1987; Luza and others, 1987; Madole, 1988), a transitional stress regime is inferred for the study region, changing from normal faulting $\left(\mathrm{S}_{\mathrm{v}}>\mathrm{SH}_{\mathrm{max}}>\mathrm{SH}_{\min }\right.$ or $\mathrm{S}_{\mathrm{V}}>\mathrm{S}_{\mathrm{N} . \mathrm{E}}>\mathrm{S}_{\mathrm{NW}}$ ) in the Texas Panhandle to strike-slip $\left(\mathrm{SH}_{\mathrm{max}}>\mathrm{S}_{\mathrm{v}}>\mathrm{SH}_{\mathrm{min}}\right.$ or $\left.\mathrm{S}_{\mathrm{NE}}>\mathrm{S}_{\mathrm{v}}>\mathrm{S}_{\mathrm{NW}}\right)$ and reverse 
Table 7. In situ stress data, south-central United States

[Study type: HF, hydraulic fracturing; $\mathrm{OC}$, overcoring. Leaders (--) indicate no data available]

\begin{tabular}{|c|c|c|c|c|c|c|c|}
\hline type & Location & Rock type & $\begin{array}{l}\text { Depth (ft from } \\
\text { ground surface) }\end{array}$ & $S_{V}(p s i)$ & $\mathrm{SH}_{\min }$ (psi) & $\mathrm{SH}_{\max }$ (psi) & $\mathrm{SH}_{\text {max }}$ (direction) \\
\hline $\mathrm{HF}^{1}$ & $\begin{array}{l}\text { Kingfisher Co., Okla., } \\
\text { eastern Anadarko basin. }\end{array}$ & - & - & - & -- & -- & N. $65^{\circ} \mathrm{E}$. \\
\hline$\alpha C^{2}$ & $\begin{array}{l}\text { Johnston Co., Okla., } \\
\text { Arbuckle uplift. }\end{array}$ & Granite & 4.5 & 0 & 519 & 1,075 & N. $94^{\circ} \mathrm{E}$. \\
\hline $\mathrm{HF}^{3}$ & $\begin{array}{l}\text { Randall Co., Texas, } \\
\text { Palo Duro basin }\end{array}$ & $\begin{array}{l}\text { Siltstone } \\
\text { Anhydrite } \\
\text { Salt } \\
\text { Salt } \\
\text { Limestone }\end{array}$ & $\begin{array}{l}1,854 \\
2,334 \\
2,434 \\
2,505 \\
2,794 \\
\end{array}$ & $\begin{array}{l}1,835 \\
2,335 \\
2,780 \\
2,950 \\
2,810 \\
\end{array}$ & $\begin{array}{l}1,110 \\
-- \\
2,915 \\
3,500 \\
1,940 \\
\end{array}$ & $\begin{array}{c}1,260 \\
\cdots \\
\cdots \\
- \\
2,650\end{array}$ & $\begin{array}{l}\text { N. } 30^{\circ} \mathrm{E} . \\
\text { N. } 40^{\circ} \mathrm{E} . \\
\text { N. } 60^{\circ} \mathrm{E} . \\
\text { N. } 60^{\circ} \mathrm{E} . \\
\text { N. } 45^{\circ} \mathrm{E} .\end{array}$ \\
\hline
\end{tabular}

\footnotetext{
${ }^{1}$ From von Schonfeldt and others (1973).

2From Hooker and Johnson (1969).

${ }^{3}$ From Borjeson and Lamb (1987).
}

Table 8. Inferred stress directions from wellbore enlargement orientations

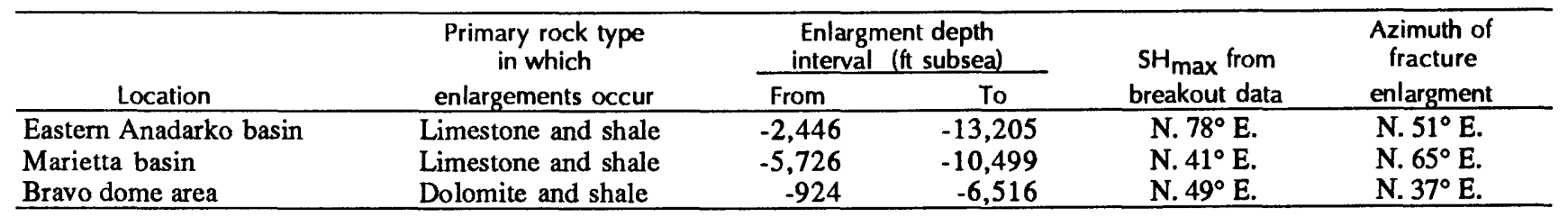

Table 9. Comparison of wellbore enlargement data from different stress regimes

[Number of wellbore enlargements is a total from all well-data sets, regardless of statistical quality]

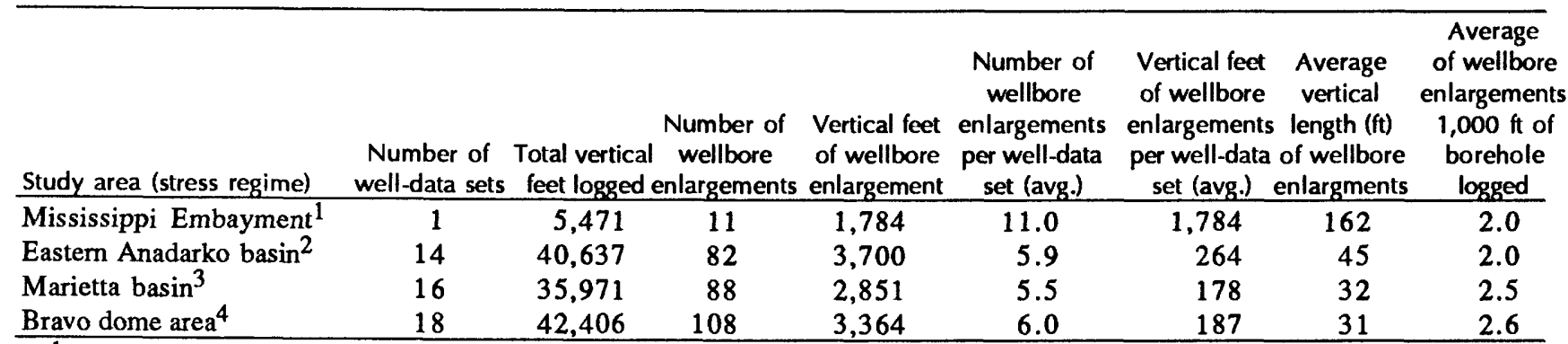

${ }^{1}$ Compressional stress regime.

${ }^{2}$ Compressional (?) stress regime.

${ }^{3}$ Extensional (?) stress regime.

${ }^{4}$ Extensional stress regime.

faulting $\left(\mathrm{SH}_{\max }>\mathrm{SH}_{\min }>\mathrm{S}_{\mathrm{v}}\right.$ or $\left.\mathrm{S}_{\mathrm{NE}}>\mathrm{S}_{\mathrm{NW}}>\mathrm{S}_{\mathrm{v}}\right)$ in Oklahoma.

Given such a limited stress-magnitude data base (tables 7,8 ), speculation on the relative magnitudes of vertical or horizontal stresses within the study region is problematic.

\section{TRANSPRESSIONAL (OBLIQUE COMPRESSIONAL) STRESSES AND FAULT-BOUNDED BLOCKS}

Many of the data sets from the Marietta basin and the Bravo dome area are bimodal (figs. $2-4,7,8,10$ ), whereas in the eastern Anadarko basin bimodal data sets of enlargement orientations are less common (figs. 2, 6, 10). The abundance of bimodal-orthogonal data sets in the Marietta basin and the Bravo dome area reflects the fracture history and suggests a local change in stress conditions related to mapped subparallel surface faults in the Marietta basin (fig. 3) and mapped subparallel basements faults in the Bravo dome area (fig. 4). Well locations in the eastern Anadarko basin (fig. 2) are distributed over a broad area and generally are not located between subparallel faults.

Preexisting fractures in an array of orientations may exist within blocks bounded by subparallel faults. The area between or above subparallel discontinuities likely has experienced an intense fracturing history 

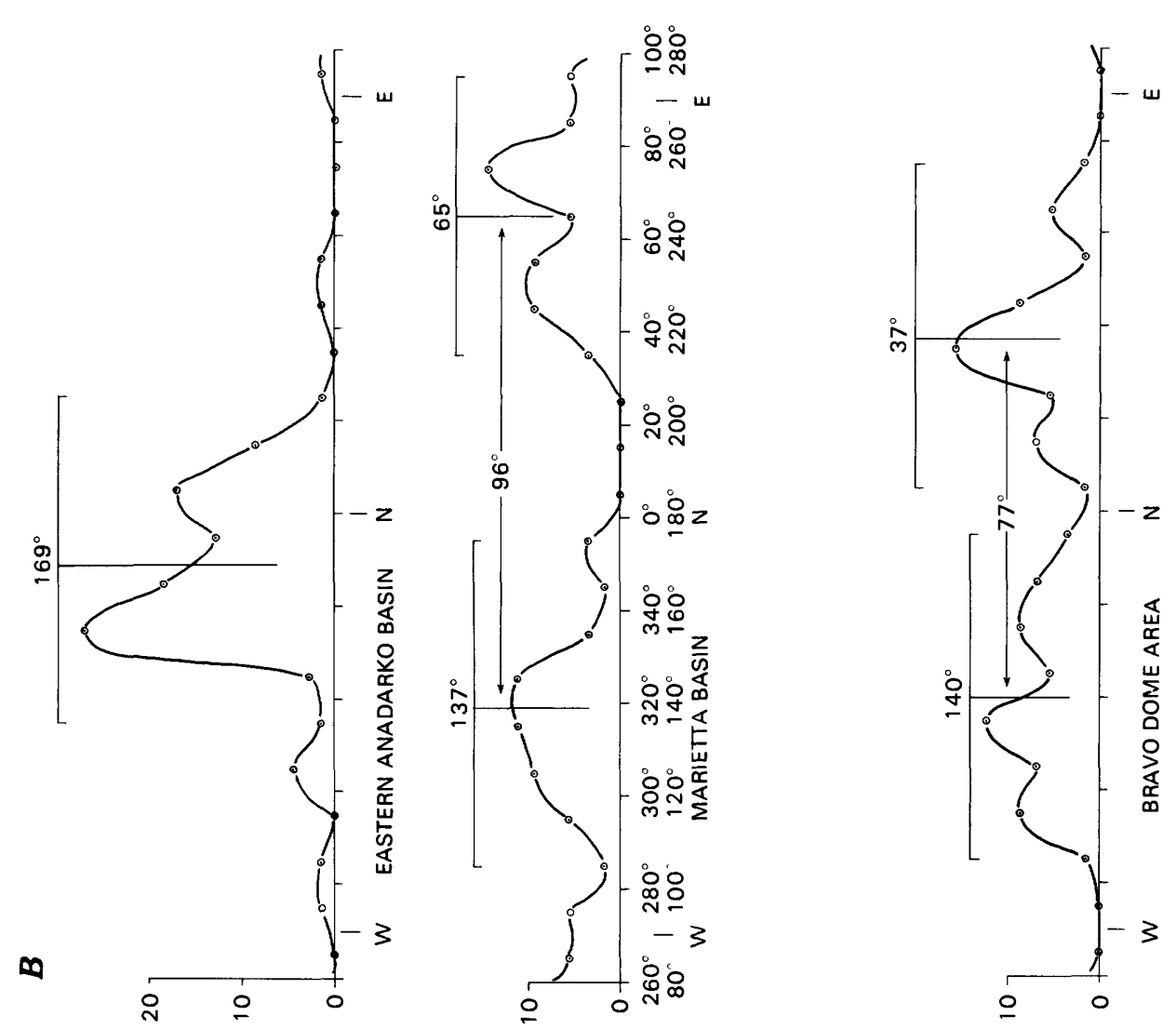

ฐ 등흥

을

定家

要要

Q

증

is

बृ

วิ

फ้은

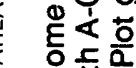

要这

赵舫

के

도

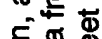

象家

뜽혀

is

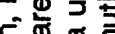

क⿺辶
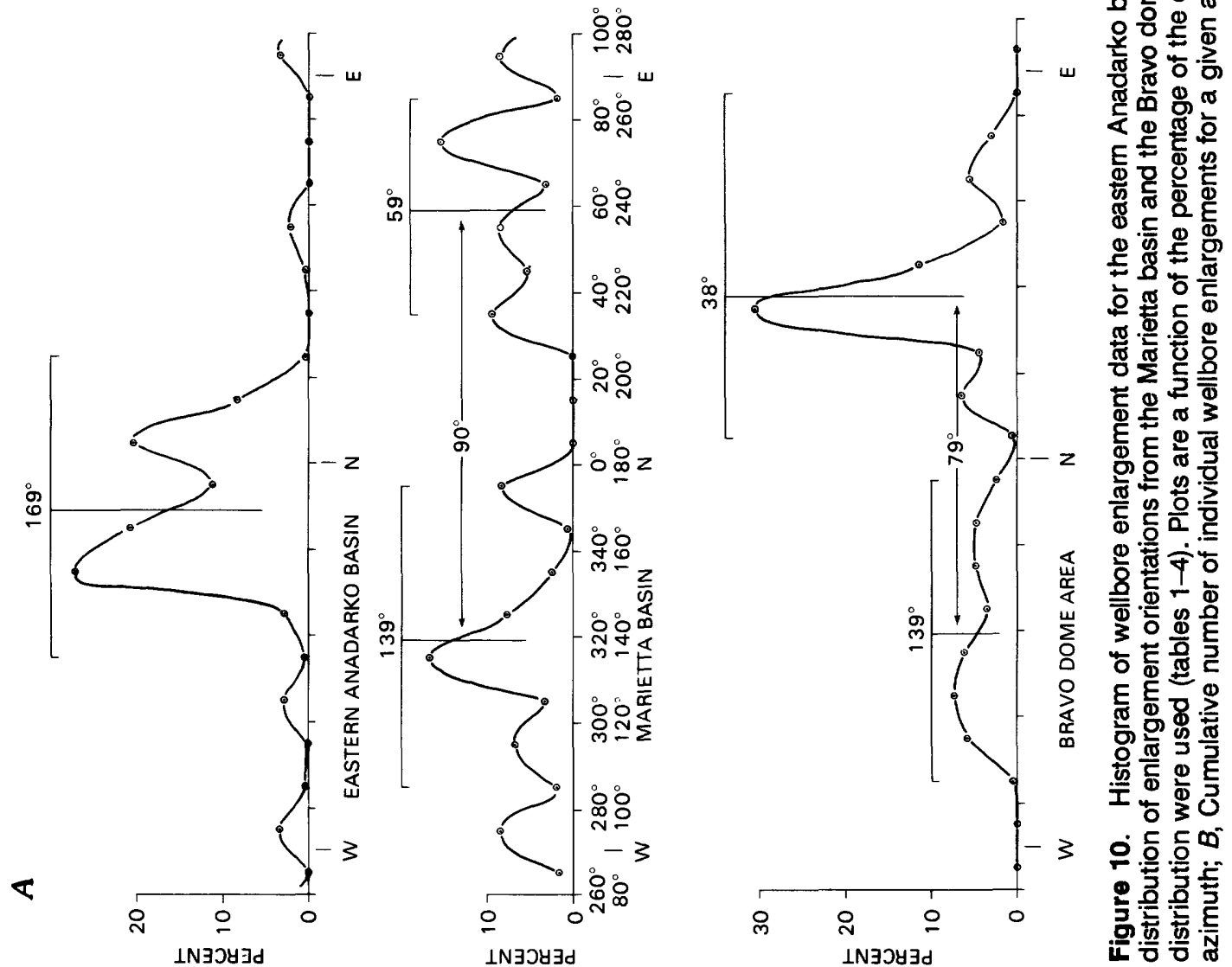
resulting in formation of sets of favorably oriented fractures or joints that would increase the likelihood of fracture-related wellbore enlargement development.

Where fracture-related enlargements have formed in response to drilling-induced hydraulic fracturing, an increase in the occurrence of fracture-related wellbore enlargements may reflect a local change in the regional stress field. Drilling-induced hydraulic fracturing is more likely to develop in a normal-faulting stress regime (Healy and others, 1984; Stock and others, 1985). An extensional (normal) faulting stress regime in the Marietta basin study area suggested by the occurrence of fracture wellbore enlargements may be a local stress anomaly in an otherwise compressional stress regime. Rogers (1984) and Hempton and Neher (1986) described structural settings in which extensional and compressional stresses develop between and near the ends of left-stepping and right-stepping en echelon strike-slip faults in response to regional horizontal compression oblique (transpressional) to their strike. Subparallel faults in the Marietta basin and Bravo dome area are not en echelon by definition; however, these two areas structurally resemble the areas described by Rogers (1984) and Hempton and Neher (1986). This similarity of structural settings and orientations of horizontal stresses suggests that extensional stress conditions (normal-faulting regime) may exist within blocks bounded by west-northwest-trending subparallel faults where $\mathrm{SH}_{\max }$ is oblique to their strike.

A comparison of the calculated orientations of $\mathrm{SH}_{\max }$ from breakout data (table 8) shows a $37^{\circ}$ difference between the eastern Anadarko and Marietta basins and a $29^{\circ}$ difference between the eastern Anadarko basin and the Bravo dome area. $\mathrm{SH}_{\max }$ orientations calculated for the Marietta basin and the Bravo dome area differ by only $8^{\circ}$. The similarities of these two differences $\left(37^{\circ}\right.$ and $\left.29^{\circ}\right)$ may correlate with the apparent similarities in structural settings of the Marietta basin and the Bravo dome area and with the possible local variation in horizontal stresses associated with the orientation of $\mathrm{SH}_{\max }$ and west-northwest-trending subparallel faults.

\section{CONCLUSIONS}

From wellbore breakout data, $\mathrm{SH}_{\max }$ is inferred to be N. $78^{\circ} \mathrm{E}$. for the eastern Anadarko basin, N. $41^{\circ} \mathrm{E}$. for the Marietta basin, and N. $49^{\circ} \mathrm{E}$. for the Bravo dome area. Bimodal sets of wellbore enlargement data are interpreted as consisting of a north-northwest to northwest mode of stress-induced breakouts and an eastnortheast to northeast mode of stress-related fracture enlargements. Fracture-related wellbore enlargements are likely associated with drilling-induced hydraulic fracturing of the wellbore or with preexisting vertical fractures or closely spaced joint sets intersecting the wellbore. The occurrence of breakouts and fracturerelated wellbore enlargements does not seem dependent on any sedimentary rock type. The stress regime for the study region most likely is transitional between normal faulting at shallow depths in the Bravo dome area of the Texas Panhandle and strike-slip and reverse faulting in Oklahoma, exclusive of the Marietta basin. Bimodalorthogonal data sets of wellbore enlargement orientations may be more likely to develop in wells in areas bounded by subparallel faults striking oblique to the $\mathrm{SH}_{\max }$ direction (transpressional stress). An extensional (normal-faulting) stress regime in the Marietta basin may be a local fault-related stress anomaly.

\section{REFERENCES CITED}

Adler, F.J., 1971, Anadarko basin and central Oklahoma area, in Cram, I.H., ed., Future petroleum provinces of the United States-Their geology and potential: American Association of Petroleum Geologists Memoir 15, v. 2, p. 1061-1070.

Amadei, Bernard, Swolfs, H.S., and Savage W.Z., 1988, Gravity-induced stresses in stratified rock masses: Rock Mechanics and Rock Engineering, v. 21, p. 1-20.

American Association of Petroleum Geologists, 1983a, Southwest/southwest mid-continent correlation chart, Hills, J.M., and Kottlowski, F.E., coordinators: American Association of Petroleum Geologist Correlation of Stratigraphic Units in North America.

1983b, Texas and Oklahoma tectonic region correlation chart, Mankin, C.J., coordinator: American Association of Petroleum Geologists Correlation of Stratigraphic Units in North America.

Batschelet, Edward, 1965, Statistical methods for the analysis of problems in animal orientation and certain biological rhythms: American Institute of Biological Sciences Monograph, $57 \mathrm{p}$.

Bell, J.S., and Gough, D.I., 1979, Northeast-southwest compressive stress in Alberta-Evidence from oil wells: Earth and Planetary Science Letters, v. 45, p. 475-482.

1982, The use of borehole breakouts in the study of crustal stress, in Zoback, M.D., and Haimson, B.C., eds., Proceedings of Workshop XVII-Workshop on hydraulic fracturing stress measurements: U.S. Geological Survey Open-File Report 82-1575, p. 539-557.

Blumling, Peter, 1986, In situ spannungsmessung in Tiefbohrungen mit hilfe von Bohrlochrandausbruchen und die spannungsverteilung in der kruste mitteleuropas und Australiens: Physics Faculty of the Karlsruhe University, West Germany, Ph.D. thesis, 135 p.

Borjeson, R.W., and Lamb, T.J., 1987, Geotechnical borehole testing report Holtzclaw No. 1 well (PD-10), Palo Duro Basin: Stone and Webster Engineering Corporation, $312 \mathrm{p}$.

Bradfield, H.H., 1968, Stratigraphy and structure of the deeper Marietta basin of Oklahoma and Texas, in Wendell, J.S., 
ed., Basins of the Southwest: American Association of Petroleum Geologists, v. 1, p. 54-70.

Brevetti, D.A., Greer, G.K., and Weis, B.R., 1984, Evaluation of fractured carbonates in the mid-continent region: Society of Professional Well Log Analysts Annual Logging Symposium, 26th, June 17-20, 1985, Schlumberger Reprint, 19 p.

Brown, R.O., 1978, Application of fracture identification logs in the Cretaceous of north Louisiana and Mississippi: Gulf Coast Association of Geological Societies Transactions, v. 28, p. 75-91.

Budnik, R.T., and Smith, Dale, 1982, Regional stratigraphic framework of the Texas Panhandle, in Geology and geohydrology of the Palo Duro Basin, Texas Panhandle-A report on the progress of nulear waste isolation feasibility studies: Texas Bureau of Economic Geology Circular $82-7$, p. $38-86$.

1987, Late Miocene reactivation of Ancestral Rocky Mountain structures in the Texas Panhandle-A response to Basin and Range extension: Geology, v. 15, p. 163-166.

Burchett, R.R., Luza, K.V., Van Eck, O.J., and Wilson, F.W., 1985, Seismicity and tectonic relationships of the Nemaha uplift and midcontinent geophysical anomaly (final project summary): Oklahoma Geological Survey Special Publication 85-2, 33 p.

Chenoweth, P.A., 1972, Principal structural features of Oklahoma: Tulsa, Okla., Penn Well Maps, scale 1:500,000.

Cox, J.W., 1970, The high resolution dipmeter reveals diprelated borehole and formation characteristics: Society of Professional Well Log Analysts Annual Logging Symposium, 11th, May 3-6, 1970, p. 1-25.

Dart, R.L., 1987, South-central United States well-bore breakout-data catalog: U.S. Geological Survey Open-File Report 87-405, 95 p.

Dart, R.L., and Zoback, M.L., 1987, Principal stress directions on the Atlantic continental shelf inferred from the orientations of borehole elongations. U.S. Geological Survey Open-File Report 87-283, 43 p.

1989, Well bore-breakout stress analysis within the Continental United States: The Log Analyst Journal, v. 30 , no. 1 , p. $12-25$.

Dutton, S.P., Goldstein, A.G., and Ruppel, S.C., 1982, Petroleum potential of the Palo Duro Basin, Texas Panhandle: Texas Bureau of Economic Geology Report of Investigation 123, $80 \mathrm{p}$

Ellis, W.L., and Swolfs, H.S., 1983, Preliminary assessment of in situ geomechanical characteristics in drill hole USW G-1, Yucca Mountain, Nevada: U.S. Geological Survey Open-File Report 83-401, 18 p.

Ervine, W.B., and Bell, J.S., 1987, Subsurface in situ stress magnitudes from oil well drilling records, an example from the Venture area, offshore eastern Canada: Canadian Journal of Earth Sciences, v. 24, no. 9, p. 1748-1759.

Feinstein, Shimon, 1981, Subsidence and thermal history of southern Oklahoma aulacogen-Implications for petroleum exploration: American Association of Petroleum Geologists Bulletin, v. 65, no. 12, p. 2521-2533.
Frederickson, E.A., and Redman, R.H., 1965, Geology of Love County, in Geology and petroleum of Love County, Oklahoma: Oklahoma Geological Survey Circular 63, p. $7-47$.

Gilbert, M.C., 1983, Timing and chemistry of igneous events associated with the southern Oklahoma aulacogen: Tectonophysics, v. 94, p. 439-455.

Gilbert, M.C., and Donovan, R.M., 1982, Geology of the eastern Wichita Mountains, southwestern Oklahoma: Oklahoma Geological Survey Guidebook 21, 160 p.

Gough, D.I., and Bell, J.S., 1981, Stress orientations from oil-well fractures in Alberta and Texas: Canadian Journal of Earth Science, v. 18, p. 638-645.

1982, Stress orientation from borehole wall fractures with examples from Colorado, east Texas and northern Canada: Canadian Journal of Earth Sciences, v. 19, 1958-1970.

Gustavson, T.C., and Budnik, R.T., 1985, Structural influences on geomorphic processes and physiographic features, Texas Panhandle-Technical issues in siting a nuclearwaste repository: Geology, v. 13, p. 173-176.

Gustavson, T.C., and Finley, R.J., 1985, Late Cenozoic geomorphic evolution of the Texas Panhandle and northeastern New Mexico-Case studies of structural control on regional drainage development: Texas Bureau of Economic Geology Report of Investigation 148, 42 p.

Haimson, B.C., and Herrick, C.G., 1985, In situ stress evaluation from borehole breakouts, experimental studies: U.S. Symposium on Rock Mechanics, 26th, Rapid City, South Dakota, 1985, Proceedings, v. 2, p. 1207-1218.

Haley, B.R., 1976, Geological map of Arkansas: U.S. Geological Survey, scale 1:500,000.

Ham, W.E., Denison, R.E., and Merritt, C.A., 1964, Basement rocks and structural evolution of southern Oklahoma: Oklahoma Geological Survey Bulletin 95, 302 p.

Healy, J.H., Hickman, S.H., Zoback, M.D., and Ellis, W.L., 1984, Report on televiewer $\log$ and stress measurements in core hole USW-G1, Nevada Test Site, December 13-22, 1981: U.S. Geological Survey Open-File Report 84-15, 47 p.

Hempton, M.R., and Neher, Kurt, 1986, Experimental fracture, strain and subsidence patterns over en echelon strike-slip faults-Implications for the structural evolution of pullapart basins: Journal of Structural Geology, v. 8, no. 6, p. 597-605.

Henry, G.E., 1968, Recent development in the Marietta Basin, in Wendell, J.S., ed., Basins of the Southwest: American Association of Petroleum Geologists, v. 1, p. 71-78.

Hickman, S.H., Healy, J.H., and Zoback, M.D., 1985, In situ stress, natural fracture distribution, and borehole enlargement in the Auburn geothermal well-Auburn, New York: Journal of Geophysical Research, v. 90, no. B7, p. 5497-5512.

Hoffman, P., Dewey, J.F., and Burke, K., 1974, Aulacogens and their genetic relation to geosynclines and a Proterozoic example from Great Slave Lake, Canada, in Dott, R.H., 
Jr., and Shaver, R.H., eds., Modern and ancient geosynclinal sedimentation: Society of Economic Paleontologists and Mineralogists Special Publication 19, p. 38-55.

Hooker, V.B., and Johnson, C.F., 1969, Near-surface horizontal stresses, including the effects of rock anisotropy: U.S. Bureau of Mines Report of Investigations 7654, $18 \mathrm{p}$.

Johnson, K.S., Branson, C.C., Curtis, N.M., Jr., Ham, W.E., Marcher, M.V., and Roberts, J.F., 1972, Geology and earth resources of Oklahoma, an atlas of maps and cross sections: Oklahoma Geological Survey Educational Publication 1, 8 p.

Johnson, K.S., Bruchfield, M.R., and Harrison, W.E., 1984, Guidebook for Arbuckle Formation field trip, southern Oklahoma: Oklahoma Geological Survey Special Publication 84-1, 23 p.

Johnson, K.S., and Denison, R.E., 1973, Igneous geology of the Wichita Mountains and economic geology of Permian rocks in southwest Oklahoma: Geological Society of America Guidebook for Field Trip 6, 35 p.

Jordan, Louise, 1957, Subsurface stratigraphic names of Oklahoma: Oklahoma Geological Survey Guidebook VI, 220 p.

1967, Geology of Oklahoma-A summary: Oklahoma Geology Survey, Oklahoma Geological Notes, v. 27, no. 12, p. 215-229.

Luza, K.V., Madole, R.F., and Crone, A.J., 1987, Investigation of the Meers fault, southwestern Oklahoma; final report: Oklahoma Geological Survey Special Publication 87-1, $75 \mathrm{p}$.

Madole, R.F., 1988, Stratigraphic evidence of Holocene faulting in the mid-continent; the Meers Fault, southwestern Oklahoma: Geological Society of America Bulletin, v. 100 , no. 3, p. $392-401$.

Mastin, L.G., 1984, The development of borehole breakouts in sandstone: Stanford, California, Stanford University, M.S. thesis, $101 \mathrm{p}$.

McGookey, D.A., and Goldstein, A.G., 1982, Structural influence on deposition and deformation at the northwest margin of the Palo Duro Basin, in Geology and geohydrology of the Palo Duro Basin, Texas Panhandle-A report on the progress of nuclear waste isolation feasibility studies: Texas Bureau of Economic Geology Circular 82-7, p. 28-37.

Moore, G.E., 1979, Pennsylvanian paleogeology of the southern mid-continent, in Pennsylvanian geology of the mid-continent: Tulsa Geological Society Special Publication 1, p. 2-13.

Morin, R.H., Newmark, R.L., Anderson, R.M., and Barton, C.A., in press, State of lithospheric stress and borehole stability at DSDP site 504B, eastern equatorial Pacific: Journal of Geophysical Research.

Morris, R.C., 1974, Sedimentary and tectonic history of the Ouachita Mountains, in Dickinson, W.R., ed., Tectonics and sedimentation: Society of Economic Paleontologists and Mineralogists Special Publication 22, p. 120-142.

Nicholson, J.H., 1960, Geology of the Texas Panhandle: University of Texas, Austin, Bureau of Economic Geology Publication 6017, p. 51-64.
Perry, W.J., Jr., 1989, Tectonic evolution of the Anadarko Basin region, Oklahoma: U.S. Geological Survey Bulletin 1866-A, 19 p.

Petroleum Information Corporation, 1982, The deep Anadarko Basin: 359 p.

1983, Oil and gas map of the United States including basins, uplifts, and basement rocks. Scale 1:3,500,000.

Plumb, R.A., and Hickman, S.H., 1985, Stress-induced borehole elongation; a comparison between the four-arm dipmeter and the borehole televiewer in the Auburn geothermal well: Journal of Geophysical Research, v. 90, no. B7, p. 5513-5521.

Presley, M.W., 1980, Upper Permian salt-bearing stratigraphic units, in Geology and geohydrology of the Palo Duro Basin, Texas Panhandle-A report on the progress of nuclear waste isolation feasibility studies: Texas Bureau of Economic Geology Circular 80-7, p. 33-40.

Preston, P.A., Harrison, W.E., Luza, K.V., Prater, Lynn, and Raja, Reddy, 1982, An evaluation of water resources by enhanced on recovery oeprations, cement field, Caddo and Grady Counties, Oklahoma: Oklahoma Geological Survey Special Publication 82-5, p. 64.

Ramelli, A.R., Slemmons, D.B., and Brocoum, S.J., 1987, The Meers Fault; tectonic activity in Southwestern Oklahoma: U.S. Nuclear Regulatory Commission NUREG/CR-4852, $51 \mathrm{p}$.

Rogers, D.A., 1984, Analysis of pull-apart basin development produced by en echelon strike-slip faults, in Sylvester, A.G., compiler, Wrench fault tectonics: American Association of Petroleum Geologists Reprint Series 28, p. 345-360.

Society of Professional Well Log Analysts, 1984, Glossary of terms and expressions used in well logging (2nd ed.): Society of Professional Well Log Analysts, 116 p.

Springer, J.E., 1987, Stress orientations from well bore breakouts in the Coalinga region: Tectonics, v. 6 , no. 5 , p. 667-676.

Stock, J.M., Healy, J.H., Hickman, S.H., and Zoback, M.D., 1985, Hydraulic fracturing stress measurements at Yucca Mountain, Nevada, and relationship to the regional stress field: Journal of Geophysical Research, v. 90, no. B10, p. 8691-8706.

Stone and Webster Engineering Corporation, 1983, Area geological characterization report for the Palo Duro and Dalhart Basins, Texas: Technical Report DOE/CH/10140-1, 429 p.

Teufel, L.W., 1985, Insights into the relationship between well bore breakouts, natural fractures, and in situ stress: U.S. Symposium on Rock Mechanics, 26th, Rapid City, South Dakota, 1985, Proceedings, v. 2, p. 1199-1206.

Tomlinson, L.W., and McBee, William, Jr., 1959, Pennsylvanian sediments and orogenies of Armore district, Oklahoma, in Petroleum geology of southern Oklahoma, v. 2: American Association of Petroleum Geologists, p. 3-52.

von Schonfeldt, H.A., Kehle, R.O., and Gray, K.E., 1973, Mapping of stress field in the upper Earth's crust of the U.S.: Final technical report, Grant 14-08-0001-1222, U.S. Geological Survey, 78 p. 
Werner, Eberhard, 1976, Graphic display of orientation data for visual analysis, in Prodwysocki, M.H., and Earle, J.L., eds., Proceedings of the Second International Conference on Basement Tectonics, p. 521-527.

Wickham, J.S., 1978, The southern Oklahoma aulacogen, in Wickham, J.S., and Denison, R.E., eds., Structural style of the Arbuckle region: Geological Society of America South-Central Annual Meeting, Field Trip 3, Guidebook, p. 9-41.

Wilhelm, S.J., and Morgan, K.W., 1986, Utilization of Landsat thermatic-mapper data for lineament analysis of the
Slick-Hills area: Oklahoma Geological Survey Guidebook 24, p. 35-39.

Zoback, M.D., Moss, Daniel, Mastin, R.L., and Anderson, R.M., 1985, Well bore breakouts and in situ stress: Journal of Geophysical Research, v. 90, no. B7, p. 5523-5530.

Zoback, M.D., and Zoback, M.L., 1981, State of stress and intraplate earthquakes in the United States: Science, v. 213, p. 96-104.

Zoback, M.L., and Zoback, Mark, 1980, State of stress in the conterminous United States: Journal of Geophysical Research, v. 85, no. B11, p. 6113-6156. 


\section{SELECTED SERIES OF U.S. GEOLOGICAL SURVEY PUBLICATIONS}

\section{Periodicals}

Earthquakes \& Volcanoes (issued bimonthly).

Preliminary Determination of Epicenters (issued monthly).

\section{Technical Books and Reports}

Professional Papers are mainly comprehensive scientific reports of wide and lasting interest and importance to professional scientists and engineers. Included are reports on the results of resource studies and of topographic, hydrologic, and geologic investigations. They also include collections of related papers addressing different aspects of a single scientific topic.

Bulletins contain significant data and interpretations that are of lasting scientific interest but are generally more limited in scope or geographic coverage than Professional Papers. They include the results of resource studies and of geologic and topographic investigations; as well as collections of short papers related to a specific topic.

Water-Supply Papers are comprehensive reports that present significant interpretive results of hydrologic investigations of wide interest to professional geologists, hydrologists, and engineers. The series covers investigations in all phases of hydrology, including hydrogeology, availability of water, quality of water, and use of water.

Circulars present administrative information or important scientific information of wide popular interest in a format designed for distribution at no cost to the public. Information is usually of short-term interest.

Water-Resources Investigations Reports are papers of an interpretive nature made available to the public outside the formal USGS publications series. Copies are reproduced on request unlike formal USGS publications, and they are also available for public inspection at depositories indicated in USGS catalogs.

Open-File Reports include unpublished manuscript reports, maps, and other material that are made available for public consultation at depositories. They are a nonpermanent form of publication that may be cited in other publications as sources of information.

\section{Maps}

Geologic Quadrangle Maps are multicolor geologic maps on topographic bases in $71 / 2$ - or 15-minute quadrangle formats (scales mainly $1: 24,000$ or $1: 62,500$ ) showing bedrock, surficial, or engineering geology. Maps generally include brief texts; some maps include structure and columnar sections only.

Geophysical Investigations Maps are on topographic or planimetric bases at various scales; they show results of surveys using geophysical techniques, such as gravity, magnetic, seismic, or radioactivity, which reflect subsurface structures that are of economic or geologic significance. Many maps include correlations with the geology.

Miscellaneous Investigations Series Maps are on planimetric or topographic bases of regular and irregular areas at various scales; they present a wide variety of format and subject matter. The series also includes 7 1/2-minute quadrangle photogeologic maps on planimetric bases which show geology as interpreted from aerial photographs. Series also includes maps of Mars and the Moon.
Coal Investigations Maps are geologic maps on topographic or planimetric bases at various scales showing bedrock or surficial geology, stratigraphy, and structural relations in certain coal-resource areas.

Oll and Gas Investigations Charts show stratigraphic information for certain oil and gas fields and other areas having petroleum potential.

Miscellaneous Field Studies Maps are multicolor or black-andwhite maps on topographic or planimetric bases on quadrangle or irregular areas at various scales. Pre-1971 maps show bedrock geology in relation to specific mining or mineral-deposit problems; post-1971 maps are primarily black-and-white maps on various subjects such as environmental studies or wilderness mineral investigations.

Hydrologic Investigations Atlases are multicolored or black-andwhite maps on topographic or planimetric bases presenting a wide range of geohydrologic data of both regular and irregular areas; principal scale is $1: 24,000$ and regional studies are at $1: 250,000$ scale or smaller.

\section{Catalogs}

Permanent catalogs, as well as some others, giving comprehensive listings of U.S. Geological Survey publications are available under the conditions indicated below from the U.S. Geological Survey, Books and Open-File Reports Section, Federal Center, Box 25425, Denver, CO 80225. (See latest Price and Availability List.)

"Publications of the Geological Survey, 1879-1961" may be purchased by mail and over the counter in paperback book form and as a set of microfiche.

"Publications of the Geological Survey, 1962- 1970" may be purchased by mail and over the counter in paperback book form and as a set of microfiche.

"Publications of the U.S. Geological Survey, 1971- 1981" may be purchased by mail and over the counter in paperback book form (two volumes, publications listing and index) and as a set of microfiche.

Supplements for $1982,1983,1984,1985,1986$, and for subsequent years since the last permanent catalog may be purchased by mail and over the counter in paperback book form.

State catalogs, "List of U.S. Geological Survey Geologic and Water-Supply Reports and Maps For (State)," may be purchased by mail and over the counter in paperback booklet form only

"Price and Availability List of U.S. Geological Survey Publications," issued annually, is available free of charge in paperback booklet form only.

Selected copies of a monthly catalog "New Publications of the U.S. Geological Survey" available free of charge by mail or may be obtained over the counter in paperback booklet form only. Those wishing a free subscription to the monthly catalog "New Publications of the U.S. Geological Survey" should write to the U.S. Geological Survey, 582 National Center, Reston, VA 22092.

Note.--Prices of Government publications listed in older catalogs, announcements, and publications may be incorrect. Therefore, the prices charged may differ from the prices in catalogs, announcements, and publications. 
